\title{
ANYWHERE-ANYTIME ENGINEERING EDUCATION IN A COMPLETE UNDERGRADUATE PROGRAM
}

\section{John M. Long}

School of Engineering, Deakin University, 75 Pigdons Road, Geelong, Victoria 3220, Australia; Tel.: (+61) 3-5227-2896; Fax: (+61) 3-5227-2167, E-mail: john.long@deakin.edu.au

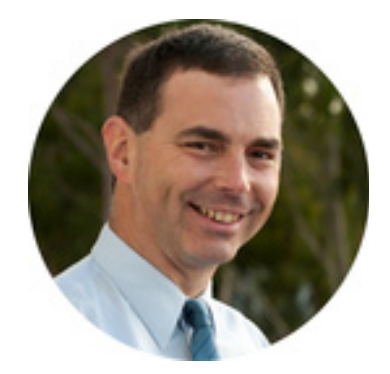

Increasingly, many STEM schools are interested in offering their educational programs online. They struggle with several difficulties associated with online education: the structure of programs and individual courses, communication among students and teachers, delivery of learning material, delivery of exams, accreditation, equity between on-campus and off-campus students, and especially the delivery of practical and laboratory training. This paper presents a longitudinal case study of engineering distance education and online learning in Australia. In the early 1990s, Deakin University faced these same challenges when it commenced teaching undergraduate engineering by distance education. It offers a full bachelor of engineering degree in both on-campus and off-campus modes. Student cohorts are approximately $70 \%$ on campus, $30 \%$ off campus. Fully accredited and part of the Washington Accord, the programs have adapted to advances in communications technology and changes in educational design. The success of the off-campus program was measured by five key performance indicators: enrollments, graduations, attrition, graduate employment, and graduate satisfaction. Data on these measures are presented from 1992 to 2016. The future direction of the school includes an emphasis on design- and project-based learning.

KEY WORDS: online engineering education, off-campus, distance learning

\section{INTRODUCTION}

Over the past 60 years, the need for a college education in order to pursue a professional career has increased significantly. Back in the 1960s, a two-year associate degree was often sufficient to begin a career in many fields. By the 1980s a bachelor's degree became 
the standard requirement. In the 21st century, a master's degree is fast becoming the standard in many areas. One thus sees an ever-increasing demand for post-high-school education. At the same time, there has been a rise in nontraditional methods of education. In spite of scepticism (Straumsheim, 2014) and many challenges (McMurtrie, 2017), distance education has grown from mostly small correspondence courses to a widely accepted means to providing higher education for people who otherwise would not be able to access it (Cleveland-Innes and Garrison, 2010). In the past 15 years, the trend has accelerated because of the rise of the internet. More recently "distance education" has often been called "online learning" and sometimes "flexible education" (Singh and Thurman, 2019). People who benefit from the flexibility brought by distance education include those in full-time employment, those who live temporarily overseas from their country of residence, such as military personnel on deployment, those who travel for work for long periods of time, those who are house bound by illness or disability, and even the incarcerated.

\subsection{Engineering Distance Education}

Twenty years ago, ABET predicted that distance education firmly lies in the future of engineering: "The face of the American student is changing. ... The need for convenience and accessibility has given rise to an increased demand for distance education as more students from varying situations seek a college education" (ABET Industry Advisory Council, 2000, p. 8). In 2005, Bourne et al. published an important paper encouraging the community of engineering educators to embrace the trend toward online education. In that paper, the authors specified three criteria that need to be met for online education in engineering to be successful and worth the investment from both universities and students:

1. "The quality of online courses must be comparable to or better than the traditional classroom.

2. Courses should be available when needed and accessible from anywhere by any number of learners.

3. Topics across the broad spectrum of engineering disciplines should be available" (Bourne et al., 2005, p. 131).

The discipline of engineering has been slower to take up distance education than other fields such as humanities or business (Mayadas et al., 2009). Twelve years ago it was noted that there were exceptionally few fully online baccalaureate engineering programs available, and perhaps accreditation restrictions were among the reasons why (Palmer and Hall, 2008). Little has changed. For example, based on a survey of publications from 
the American Society for Engineering Education, the Online Learning Consortium, and other sources, while there are a number of engineering master's degrees offered online (Whiteman, 2012), there are few complete online undergraduate degrees in engineering currently taught in the United States. Table 1 lists online bachelor of science programs in engineering (not engineering technology and not IT) offered in the United States. Six universities offer or have offered such a program. Of these, only three programs are listed as having ABET accreditation (ABET, 2020). To this author's knowledge, the only other American institution offering a BS degree in engineering under the heading "distance education" is North Carolina State University (L. Krute, private communication). Furthermore, there are no published long-term studies on the success or otherwise of any online engineering program.

TABLE 1: Complete online BS programs in engineering offered in the USA

\begin{tabular}{|c|c|c|}
\hline Institution & $\begin{array}{c}\text { Undergraduate } \\
\text { Program }\end{array}$ & Ref. \\
\hline Georgia Tech & $\begin{array}{l}\text { Civil, computer } \\
\text { engineering }\end{array}$ & Hughes and Frost, 2001 \\
\hline $\begin{array}{l}\text { Stony Brook } \\
\text { University }\end{array}$ & $\begin{array}{l}\text { Electrical } \\
\text { engineering }\end{array}$ & Tang et al., 2015 \\
\hline $\begin{array}{l}\text { American } \\
\text { Military } \\
\text { University }\end{array}$ & $\begin{array}{l}\text { Electrical } \\
\text { engineering }\end{array}$ & $\begin{array}{c}\text { https://www.apu.apus.edu/academic/schools/science- } \\
\text { technology-engineering-and-math/bachelors/electrical- } \\
\text { engineering.html }\end{array}$ \\
\hline $\begin{array}{c}\text { Arizona State } \\
\text { University }\end{array}$ & $\begin{array}{l}\text { Engineering } \\
\text { management, } \\
\text { software } \\
\text { engineering, } \\
\text { electrical } \\
\text { engineering }\end{array}$ & Phillips and Saraniti, 2016 \\
\hline $\begin{array}{l}\text { University of } \\
\text { North Dakota }\end{array}$ & $\begin{array}{l}\text { Chemical, civil, } \\
\text { electrical, } \\
\text { mechanical, } \\
\text { petroleum, and } \\
\text { geological } \\
\text { engineering }\end{array}$ & https://und.edu/programs/index.html \\
\hline $\begin{array}{l}\text { Pennsylvania } \\
\text { State } \\
\text { University }\end{array}$ & $\begin{array}{l}\text { Software } \\
\text { engineering }\end{array}$ & $\begin{array}{c}\text { https://www.worldcampus.psu.edu/degrees-and- } \\
\text { certificates/penn-state-online-software-engineering- } \\
\text { bachelors-degree/overview/ }\end{array}$ \\
\hline
\end{tabular}

Nonetheless, a large number of engineering schools are trialling individual courses taught by online and distance learning [see, for example, Buechler et al., (2014), Kilicay-Ergin 
and Laplante (2013), Krute et al. (2012), Scott et al. (2012)]. One reason for this is that providing education "online" has made delivering teaching materials much easier. In the late 1990s, teaching material was typically delivered through conventional mail. Study materials were principally paper-based: textbooks, printed study guides, assignments mailed to instructors and then returned to the students by mail. Now almost all course and learning materials can be delivered via websites. Sophisticated learning-management systems now exist to manage everything from text delivery to assignment submission to class communication. Video recording of lectures is also becoming common, and uploading video recordings to course websites is now straightforward and routine.

By means of an Australian case study, the aim of this paper is to provide some evidence for the possibility to train professional engineers by distance education/online learning, across multiple engineering disciplines, and that such a program can be viable in the long term. Various pedagogies that have been used are presented, some quite novel in their day. The author presents descriptive data on the long-term performance of the overall program as measured against six criteria. He also considers the difficult problem of laboratory and hands-on learning, and presents a number of solutions that in his experience have been employed. Finally this paper looks to the future and introduces efforts to bring collaborative and active pedagogies to online cohorts.

\subsection{Distance Education in Australia}

Australia has a small population in a large continent. Even though they occur away from the centers of population, much of Australia's wealth came from mining, farming, grazing, and wool, contributing to the bulk of the nation's export income. It is natural then that people in these professions wield considerable political influence in Canberra, the nation's capital. As a result, the government has supported its population "in the bush." Even though most people live in a handful of coastal cities, there are still plenty of students who live in remote towns, mines, farms, and cattle stations.

Distance education in Australia dates back to the 1920s, with early correspondence courses (Reiach et al., 2012) and the well-known School of the Air (Ashton, 1978). In 1988, the Australian Government established eight centers of distance education, shown in Table 2 (Dawkins, 1988). By concentrating university distance education into eight national centers, the government hoped to increase both the quality of distance education nationally and its ease of access (Herrmann et al., 1991). 
TABLE 2: Australian centers of distance education 1988

\begin{tabular}{|cc|}
\hline State & Institution \\
Queensland & Central Queensland University \\
Queensland & University of Southern Queensland \\
South & South Australian College of Advanced Education \\
Australia & \\
New South & Charles Sturt University \\
Wales & \\
New South & University of New England \\
Wales & \\
Western & Curtin and Murdoch Universities, and the Western \\
Australia & Australian College of Advanced Education \\
Victoria & Monash University Gippsland \\
Victoria & Deakin University \\
\multicolumn{2}{c}{} \\
\hline
\end{tabular}

The Australian engineering profession recognized that distance education has a role to play in training engineers from remote areas (Lloyd et al., 2001). The central research question considered here is whether it is possible to fully train and qualify engineers at the undergraduate, baccalaureate level by means of distance and online education in difficult conditions such as those found in Australia. Of the 34 Australian universities that teach engineering, four offer a complete bachelor of engineering by online learning: Charles Darwin University in the Northern Territory, University of Southern Queensland, Central Queensland University, and Deakin University in Victoria (Lipnicki, 2018).

\section{DEAKIN UNIVERSITY SCHOOL OF ENGINEERING}

Deakin University (www.deakin.edu.au), founded in 1974, operates from four campuses in Melbourne, Geelong, and Warrnambool, Victoria, with an enrollment of 61,000 students (Holt and Palmer, 2010). Originally designed to offer degrees both on campus and by distance education (Jevons, 1984), about $25 \%$ of its students study in off-campus mode. Deakin's School of Engineering was founded in 1991, with the mission to offer innovative undergraduate programs and to be a major provider of distance education in engineering (Briggs and Hodgson, 2000; Long and Baskaran, 2004; Palmer, 2011). The bachelor of engineering took its first enrollments in 1992 (manufacturing) and 1993 (mechatronics and environmental). At the undergraduate level, Deakin currently offers six engineering majors:

- Electrical and Electronics Engineering

- Civil Engineering 
- Mechanical Engineering

- Mechatronics Engineering

- Software Engineering

The program takes four years full-time to complete. The various subjects are divided up into credit-points, usually one per course. A one credit-point course requires the student to put in approximately 150 total hours of class work and private study. Prior to 2016, the final-year capstone project was a double course of two credit-points. Each year level has eight credit-points, four per semester. The program is accredited by the Institution of Engineers, Australia (Engineers Australia, 2020), and the educational design is guided by the principles outlined in its list of required competencies for graduate engineers (Engineers Australia, 2017). The fundamental competencies required by graduate engineers in Australia are centered on three key areas: knowledge and skill base appropriate to the specific engineering discipline; ability to apply engineering methods, tools, and resources; and professional and personal attributes related to ethics, communication, creativity, self-management, and teamwork. Engineers Australia is also a signatory to the Washington Accord, an international agreement that accredits engineering degrees worldwide. This allows engineers who obtain their qualifications in Australia to work as engineers in several overseas countries, including the United States (International Engineering Alliance, 2020). With the exception of environmental engineering, all courses in the program are offered in both off-campus and on-campus modes, essentially two sections of the same course.

Table 3 shows a typical structure for one of its majors prior to a recent program redesign. In this structure, all engineering majors had a common first year. Engineering Practice was an introductory course on the profession and teaches the fundamentals of communication, teamwork, research, and project management (Palmer, 2004). Engineering Physics covers basic mechanics specific to engineering, especially mechanical and civil (Long, 2015). Fundamentals of mathematics for engineering, such as calculus, matrix operations, and complex numbers, are taught in the two courses Applied Algebra and Statistics, and Introduction to Mathematical Modelling. The beginnings of design skills were developed in Engineering Graphics and CAD. Programming for Engineers (Wells et. al., 2012) teaches $C$ programming (essential for microprocessor and microcontroller applications), and specific software packages such as MATLAB. A taste of specific fields of engineering were given in Electrical Systems and Engineering Materials. The program content diverged into its various disciplines in the second year of study. In this structure, all students in all majors studied three courses of engineering management, and three credit-points of course workwere dedicated to final-year capstone projects. The only courses not offered 
TABLE 3: Sample program map for the Deakin civil engineering major. The full program is 32 credit-points of course work.

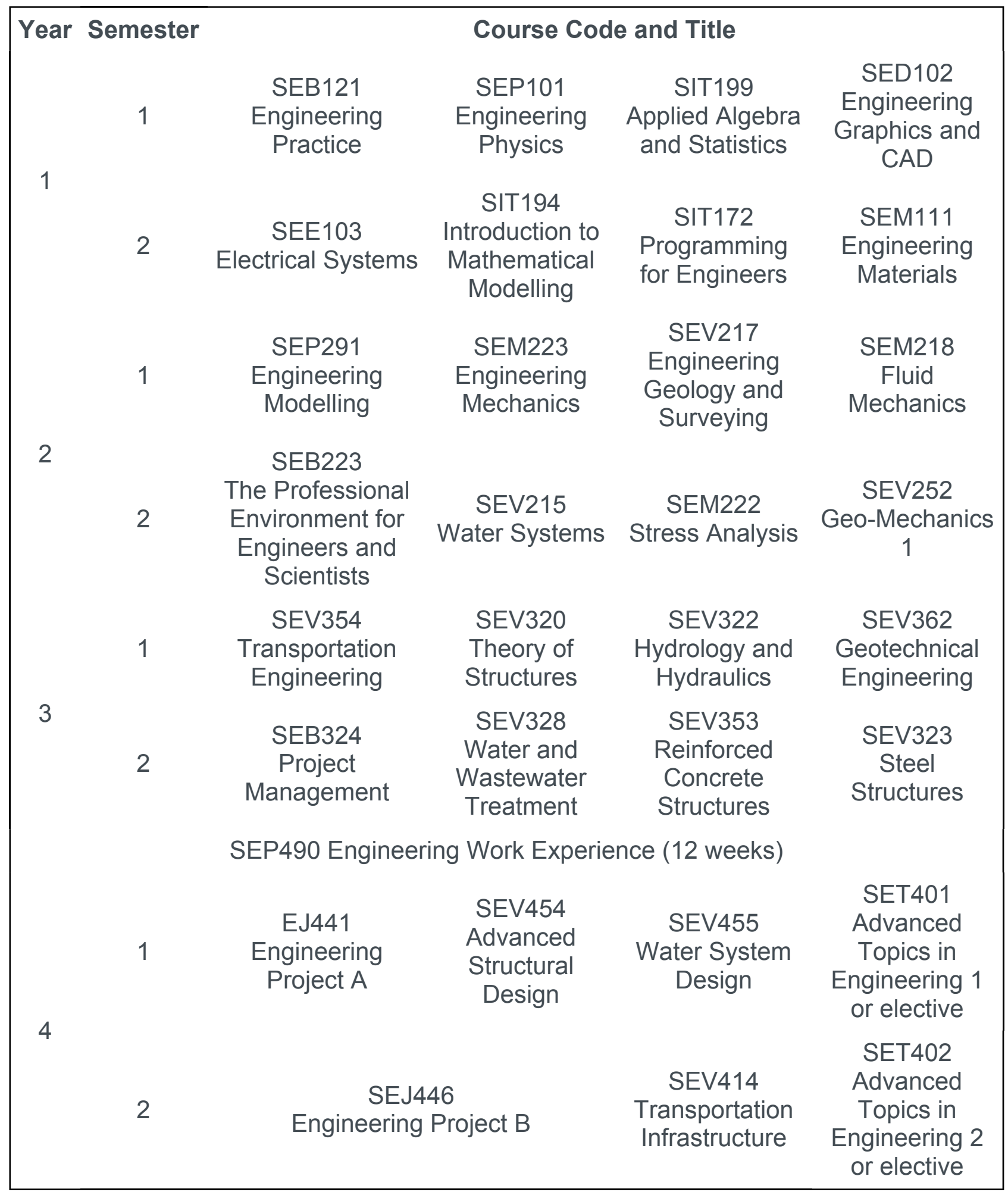


by the School of Engineering are the programming and mathematics courses. These are delivered by the School of Information Technology, which also offers its academic programs on-campus and online (Coldwell et al., 2008; Deakin University, 2020; HainsWesson et al., 2015).

The degree itself does not distinguish between off-campus mode and on campus. All students study the same program. Over the course of their study, many students switch from on campus to off campus and vice versa. Early in 1994, the average age of all offcampus students was 32 years (Briggs, 1995). A later study found that typical off-campus students are between 22 and 40 (average 34) years old, have a full-time job, often in an engineering field (such as manufacturing or mining), and often have a family (Palmer et al., 2008). They enrol in the off-campus program to increase their educational qualifications and assist with career advancement. On average, around 30\% of the school's total enrollments have been off campus. Off-campus students generally take a half-time study load. While the majority of off-campus students reside in either Melbourne or Geelong, significant numbers live in rural areas and interstate (Fig. 1). Especially in the first 15 years of the school, significant numbers of off-campus students actually lived overseas (Table 4).

\section{INNOVATIVE PEDAGOGY}

The pedagogy used by the school for distance teaching can be separated into early and late forms, distinguished by the education technologies available. In both cases the school has been at the forefront of innovation in curriculum design, technology, and course delivery, by either developing new teaching methods (lab practicals, for instance) or rapidly adopting new technologies (such as interactive courseware, advanced video capture, and synchronous online tutorials).

\subsection{Early Years}

The early period is 1992-2008 (Ferguson, 1998). In this era, off-campus students learned primarily by studying printed text material. This included both textbooks and study guides, written by the lecturers, published by the university, and distributed to students by conventional mail. Students mailed their written work to the university to be assessed by the teaching staff, and then the graded assignments were mailed back to the students. This was a very slow process, with typical turnaround times of three weeks from when the student submitted the assignment to when he or she received the grade and feedback. Student communication with the lecturer was mainly by telephone, fax, or email. Some lecturers produced short video presentations on specific aspects of the course material, and the videos (first VHS tape, then DVDs) were mailed to students at the start of the semester. By 2004 all courses had basic websites, online noticeboards, and discussion 


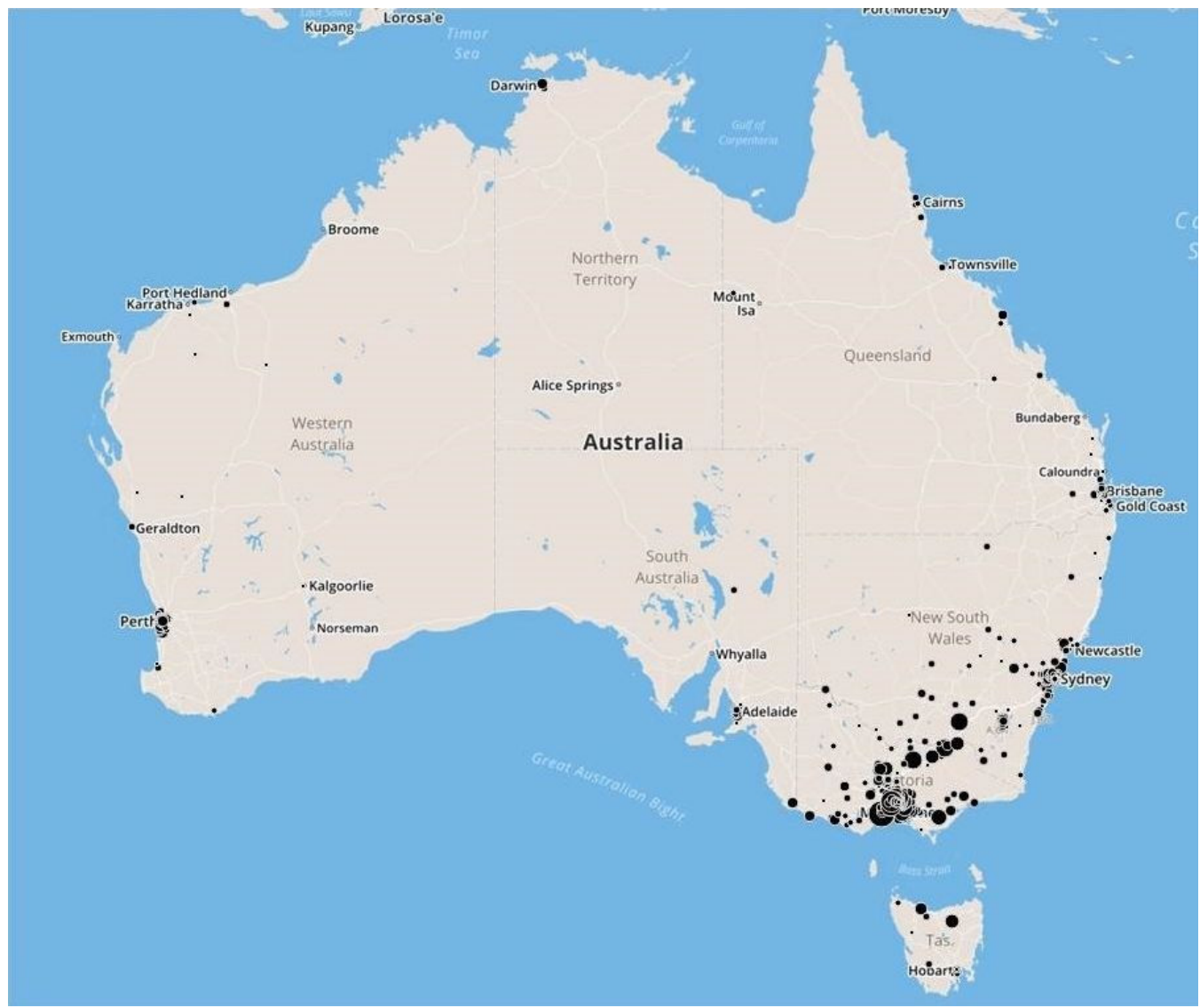

FIG. 1: Dots show comparative home location data for Deakin engineering off-campus students residing in Australia 2013-2016. The heavier the dot, the greater the enrollment number from that location.

TABLE 4: Approximate total off-campus course enrollments for students living overseas by world region, 2001-2016

\begin{tabular}{|cc|}
\hline Country or Region & Enrollments \\
New Zealand & 70 \\
Malaysia/Singapore & 942 \\
India and Sri Lanka & 42 \\
China, Hong Kong, Burma, & 11 \\
and Mongolia & 4 \\
Japan & 7 \\
Africa & 6 \\
North America & 11 \\
Europe & 6 \\
Middle East &
\end{tabular}


forums as part of a university-wide learning-management system (Palmer and Holt, 2010). Closer to the end of this period, course websites were used for most communication and also for providing supplementary teaching materials to students, such as lecture notes and solutions to sample problems. Online drop boxes for assignments were also introduced (Palmer, 2005). Sometimes off-campus students were offered supplementary instruction for their lab work. When off-campus students performed much of their practical work at home, alternative activities were developed to cater for at-home experimental work (Ferguson, 1998).

\subsection{Later Years}

The later period, 2008 to the present, saw more sophisticated use of websites (Palmer, 2012b), wider use of video, and the introduction of online, synchronous classes. In the present, apart from laboratory practicals and textbooks, nearly all course material is delivered online. The present learning-management system is built on the Desire-2-Learn software platform (Horn and Owen, 2010).

Typical components of a course website include (Fig. 2) the following:

\section{SEM216 - Stress And Failure Analysis}

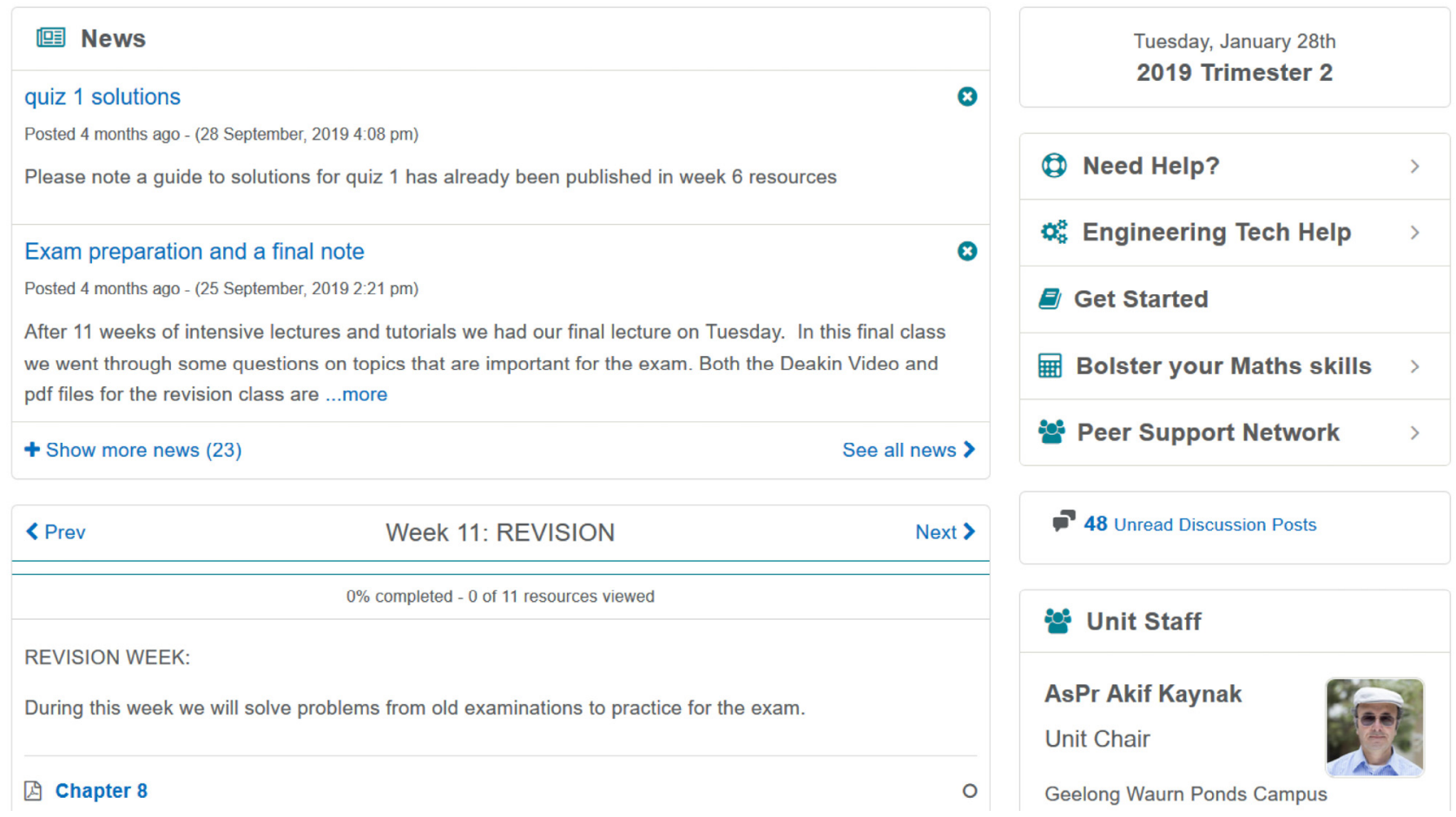

FIG. 2: Sample home page from the website for a second-year mechanics course 
- A short welcome video from the lecturer.

- An announcement page.

- A course overview area.

- A laboratory experiments area.

- Online study guides, topic by topic and week by week. These study guides are a mixture of text and video.

- A discussion forum.

- An assignment drop box for students to upload their work for assessment.

- An exam revision page.

Individual courses are organized according to the unit-module-topic model (Simonson et al., 2012). Each course is considered as a unit, which is divided into three-five modules, each of 2-4 weeks duration. Each module is broken down into individual topics, and each topic is associated with a set of learning objectives. Teaching materials are developed by the teaching faculty with the help of a team of educational developers, editors, and experts in developing websites.

Several software packages used by engineers are now available to off-campus students by remotely accessing on-campus servers. Instead of the student installing the software on an at-home computer or going on campus to access this software in a computer lab, the student logs into an on-campus server from home via a remote-desktop utility available with most operating systems and runs the software program by remote control. Thus a student in another state or living in a remote area can access high-end engineering software without the expense of a powerful computer and without the school being required to mail installation CDs to the student. Courses are evaluated yearly by the students (Palmer, 2012a) and reviewed regularly to keep them up to date with engineering developments, improvements in communication technology, and student expectations (Hall et al., 2007).

\subsection{Use of Video}

Videos are streamed via the course websites and made available for downloading in multiple formats (Palmer, 2007; Wells et al., 2012). There are several ways in which video has been employed for both off-campus and on-campus teaching, and the sophistication of these videos has increased year by year. Since 2009, on-campus lectures have been automatically recorded and made available to all students (Echo360, 2020). In other 
cases, on-campus lecture recordings were divided up into short (10-15 minute) segments and imbedded topic by topic into study guides within course websites (Long, 2015). Many lecturers produce their own teaching videos by means of desktop-capture software such as Camtasia (TechSmith, 2020). They use modern devices such as a tablet or PC to simultaneously deliver lectures and make recordings for off-campus students to view in their own time (Joordens, 2016). Document cameras often supplement what can be recorded directly from a computer screen (Fig. 3). When individual lecturers produce their own videos, this makes the whole operation less labor intensive and thus reduces costs to the school. The physics team produced another series of videos to introduce students to the lab experiments and expedite their use of the equipment and data loggers (Long et al., 2014b). More recently, intelligent-tutoring systems have become available, which combine text, video, and quizzes into an integrated educational package that can adapt to a student's interaction, preferences, and needs (Bagheri, 2015). One lecturer implemented interactive courseware by Smart Sparrow in a third-year course on heat transfer (Leigh, 2016). Lastly, another recent innovation for delivering online lecture material is the light

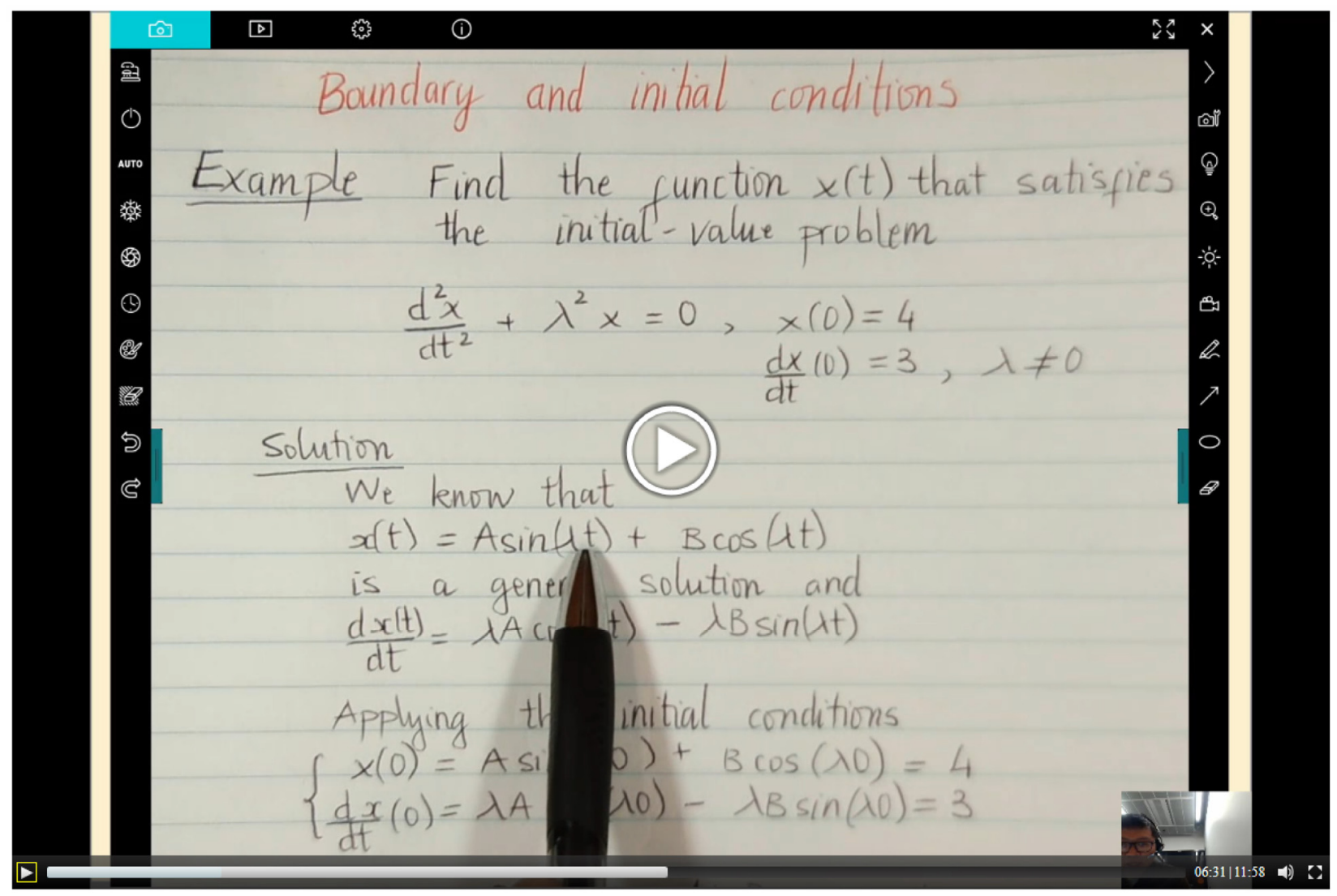

FIG. 3: Screenshot of a video used for teaching engineering mathematics. A document camera was used to record the writing, and the presenter's face appears in the lower-right corner. 
board (Birdwell and Peshkin, 2015). Figure 4 shows that videos produced this way show the presenter, what is written on the board in front of the presenter, and allow for demonstrations. As has been recommended in the context of medical education (Dong and Goh, 2015), the videos currently being produced tend to be short and targeted, aligned with the learning outcomes, engaging, and of high quality.

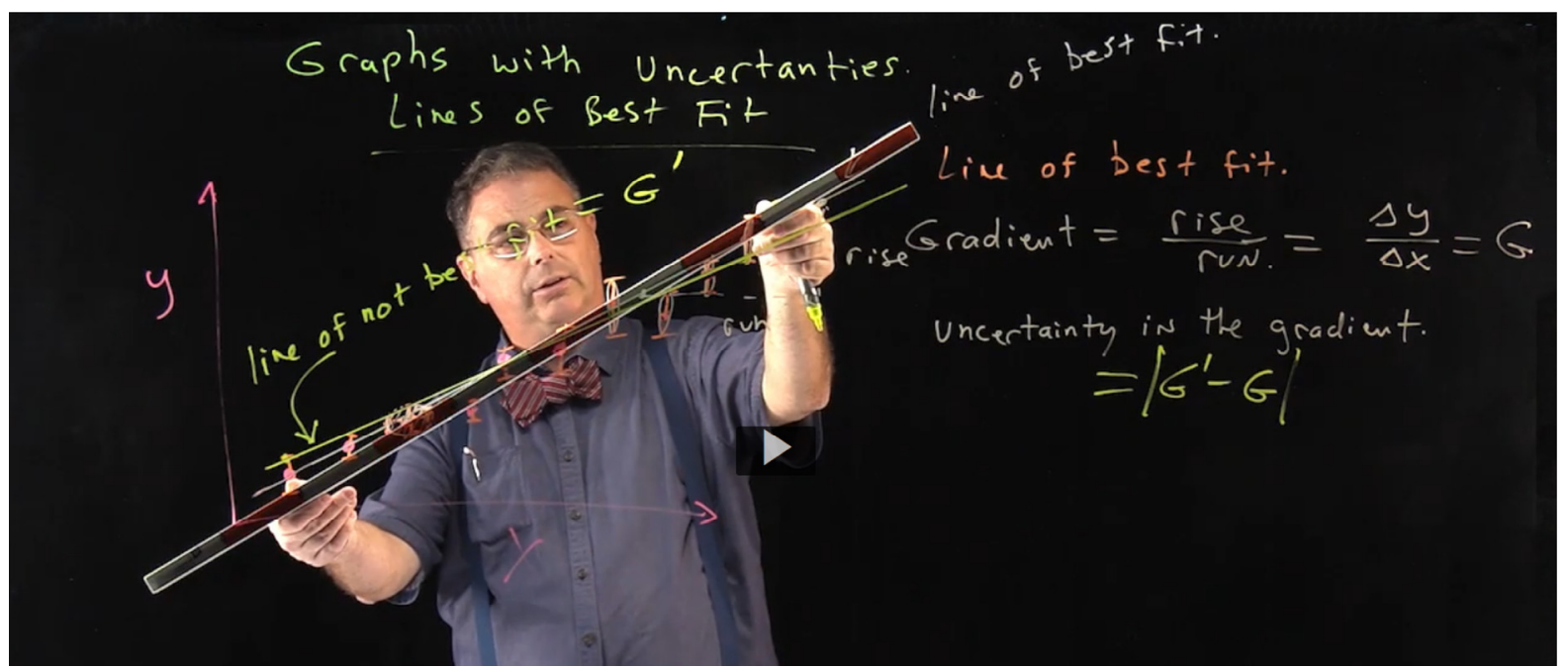

FIG. 4: Use of a lightboard to record a short tutorial on uncertainties in measurement

\subsection{Synchronous Online Classes}

Another innovation (Fig. 5), the school was one of the first to deliver real-time tutorials by web-conferencing. Like\& online chat rooms, this is a form of synchronous\& communication among teachers and students. Online tutorials help to overcome the delay in communication that often exists between lecturer and student. It also goes a long way toward easing the isolation that many off-campus students feel. Since 2013, all engineering courses have delivered web-based real-time tutorials (Long et al., 2014a). These tutorials are delivered mainly in the evenings, when most off-campus students are home from work. Every course in every major runs online tutorials one to two hours per week during semester. The current software platform used for the online tutorials is Blackboard Collaborate (Blackboard Inc., 2020). These online sessions can also be recorded for students who miss them. 


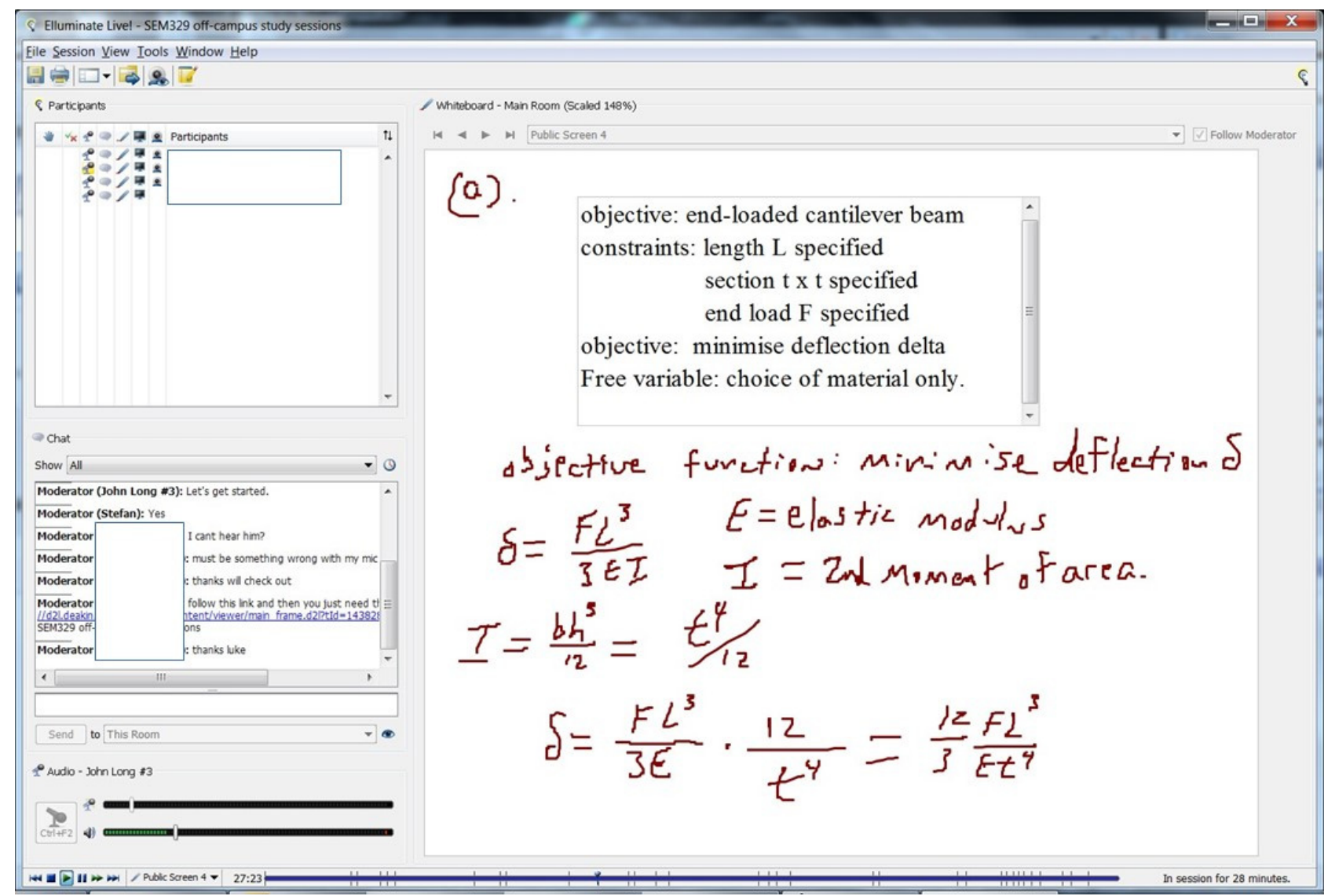

FIG. 5: Example of using web-conferencing software to deliver a tutorial to off-campus students in mechanical engineering

\subsection{Laboratory and Practical Work}

Practical experience through lab classes, workshops, and work placements are essential elements in any engineering program (Feisel and Rosa, 2005). In distance education and online learning, providing students with practical education has always been the biggest challenge for the educator (Walkington et al., 1994). The obvious solution to this problem is to run dedicated practical or lab classes on weekends or evenings. This works for offcampus students who live close to the school or university but is impractical for students who live more than a day's drive from the home campus. How does one transmit practical knowledge to off-campus students? Deakin has addressed this problem in eight basic ways (Hall et al., 2006):

1. Weekend lab classes (Long et al., 2012); the majority of courses do this.

2. Video-recorded experiments (Fig. 6).

3. Computer simulations and games (Joordens, 1998, 2012). 
4. Lab kits and associated at-home experiments (Jones and Joordens, 2003; Long et al., 2012).

5. Remote-controlled lab experiments (Lal et al., 2018; Lemckert and Florance, 2002; Lyons, 2017).

6. At-home design projects (Chandrasekaran et al., 2015; Long and Hartas, 2005).

7. Web-broadcasting of lab classes (Long et al., 2013).

8. An intensive residential school.

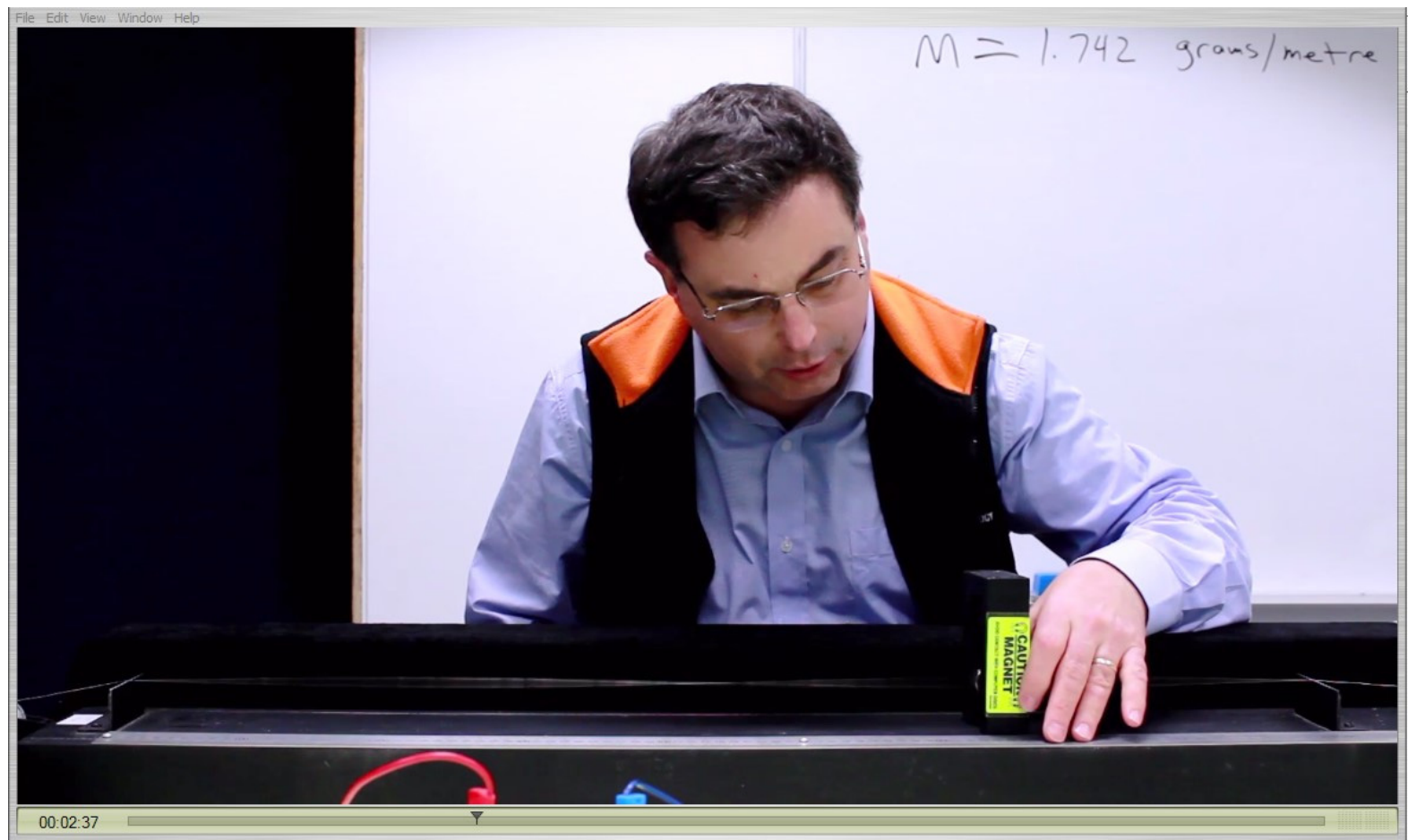

FIG. 6: Video recording of an experiment on standing waves in first-year physics. The presenter called out the measurements as he collected them for the students to write down.

Deakin was among the first of the universities to employ both remote laboratories and lab kits in practical teaching. The laboratory programs in the school are the same for offcampus students as they are for on campus. For any course that has a laboratory component, off-campus students perform the same activities as the on-campus students. The experimental procedures, lab instructors, lab manuals, reporting requirements, and assessments are the same. 


\subsection{Residential Schools}

To satisfy accreditation requirements, since 2005 the school has run on-campus residential schools for off-campus students (Long et al., 2016b). The purpose of the residential schools is for off-campus students to meet the engineering faculty, gain some first-hand exposure to engineering practice by means of guest lectures and site visits, engage in group activities, meet other students, perform practical exercises and lab classes, and deliver in-person project presentations. The requirements were developed by Engineers Australia in consultation with members of the Washington Accord (Bradley, 2007) and are modelled after residential schools developed by the University of Southern Queensland (Morgan et al., 1999).

The Engineers Australia policy specifies that an off-campus engineering program should include on-campus components to increase the interaction between both students and faculty and among the students themselves, encourage the development of learning communities, and so that the academics, who certify that the students have attained the learning attributes required of engineering graduates, can verify first-hand the students' practical capabilities. Engineers Australia also wants online students to gain some firsthand exposure to professional engineers in action and the research activities of the school. The policy mandates that an off-campus student must attend on-campus activities equivalent to one week for every semester of full-time study. It appears that this policy is unique to Australia and is not a mandated accreditation requirement in other countries (Palmer and Ferguson, 2008).

As much as possible, for all courses, all the assessments, exams, assignments, and labs have been identical for on- and off-campus students. Exams for off-campus students are conducted in supervised exam centers located throughout Australia and overseas. The university has both administrative infrastructure and quality-assurance processes in place so that books and library resources can be efficiently delivered anywhere in the world; course materials are professionally produced and updated; online systems work effectively; and exam papers are quickly delivered for grading (Holt and Palmer, 2010; McKnight, 2006).

\section{METHODOLOGY FOR MEASURING SUCCESS}

There are a number of ways to determine the success of an educational program over time. One way is to track enrollment numbers. Do they increase, decrease, or remain steady? Another measure is the count of graduates. A third measure is to count the number of students who drop out of the program and compare that figure with the total number of students. The average time it takes to complete the degree can also be measured. Since engineering studies are a pathway to a very specific career, one may 
survey graduates and count those who are in full-time employment, and then compare those numbers with state and national averages. Finally, students can also be surveyed directly about their satisfaction with the whole major.

These six measures have been applied yearly as a measure of the program's success and as instruments for quality checks and continuous improvement. Data of student enrollments, attrition, and graduation were recorded for various years from 1992 to 2016. One may define attrition rate, $A R$, as the difference in the number of students returning from one year to the next, accounting for the number who have graduated, relative to the beginning student numbers:

$$
A R=\frac{N_{A}-\left(N_{B}+G\right)}{N_{A}}
$$

Here, $N_{A}$ is the total number of students enrolled in the first of two consecutive years on March 31st, three to four weeks after first semester starts. $N_{B}$ is the total number of students enrolled in the following year on the same date. $G$ is the number of students who graduate during that year. Data for attrition rates were obtained for the years 2007-2016, on campus and off campus. The on-campus attrition rate was relative to on-campus student numbers. Similarly, the off-campus attrition rate was relative to off-campus student numbers. The average time graduates took to complete the course was also measured for the seven-year period 2010-2016.

Graduate employment and overall student satisfaction were measured by participation in two national surveys for graduates: the Australian Graduate Destination Survey (GDS) and the Australian Course Experience Questionnaire (CEQ). Both surveys were given to all graduating students in Australia about four months after they completed their respective majors (Harris and James, 2010). The GDS surveyed graduates on employment, further study, occupation, and salary, and sought to provide information on national trends by occupation and field of study. One of the data sets was, for a given field of study, how many graduates were available for full-time employment, how many were actually in fulltime employment, how many were in part-time employment but seeking to work full time, and how many were unemployed but seeking employment. Each university administered the survey, and the analysis and reporting was done by the Social Research Centre (2020), who published an annual national report.

The CEQ was also administered by the local university, and national analyses were performed and published by Graduate Careers Australia. The CEQ explored the perceptions of graduates on the teaching they experienced, learning materials, assessment, motivation, support they received from the university, and the community of learners in their majors. The survey results were reported for four core measurement 
scales and seven optional scales on which universities chose whether to survey graduates or not (Table 5). The survey for each scale posed one or more questions, to which agreement or disagreement was indicated by means of a five-point Likert scale $(1=$ strongly disagree, $5=$ strongly agree, $3=$ neither agree nor disagree). For instance, the good-teaching scale posed six statements on which graduates indicate their agreement:

- "The staff put a lot of time into commenting on my work.

- The teaching staff normally gave me helpful feedback on how I was going.

- The teaching staff motivated me to do my best work.

- My lecturers were extremely good at explaining things.

- The teaching staff worked hard to make their subjects interesting.

- The staff made a real effort to understand difficulties I might be having with my work."

TABLE 5: Course Experience Questionnaire (CEQ) areas of enquiry and reporting

\begin{tabular}{|ccc|}
\hline Core Scales & \multicolumn{2}{c|}{ Optional Scales } \\
Good teaching & Appropriate workload & Learning community \\
Generic skills & Clear goals and standards & Learning resources \\
Overall satisfaction & Graduate qualities & Student support \\
Appropriate assessment & Intellectual motivation & \\
\hline
\end{tabular}

The overall-satisfaction scale posed only one statement: "Overall, I was satisfied with the quality of this course." ("Course," in this context, refers to the entire major program.) For the years 2003-2015, data for these two scales (good teaching and overall satisfaction) were collected from graduating off-campus and on-campus students. The results were compared against each other and against national average results (when available) for all engineering programs. For the GDS, the total number of Deakin students responding each year varied between 22 and 74, with the average being 40. For the CEQ, Deakin's number of responses varied between 33 and 79 , with an average of 51 .

This paper therefore proposes six key performance indicators for the long-term success of an online bachelor's program in engineering:

1. Steady or increasing enrollments

2. A regular stream of graduates

3. Low, or at least competitive attrition rates 
4. Reasonable completion times

5. High employability of the graduates

6. Satisfied graduates

\section{RESULTS}

Figure 7 shows enrollment statistics in the School of Engineering over the 25 years 1992 -2016. The graph shows both total and equivalent-full-time (EFT) enrollments. In a given year, as there are eight credit-points per year in a full-time program, EFT is determined by taking the total number of course enrollments, dividing this number by the product of eight times the number of actual students by head count, then multiplying this quotient by the total head count. An initial five years of growth was followed by another five years of relatively steady enrollments. Since 2001, while the on-campus enrollments increased almost every year, the off-campus enrollments dropped after a peak in 2003-2004. The years of lowest off-campus enrollments were 2008-2009, in the wake of the global

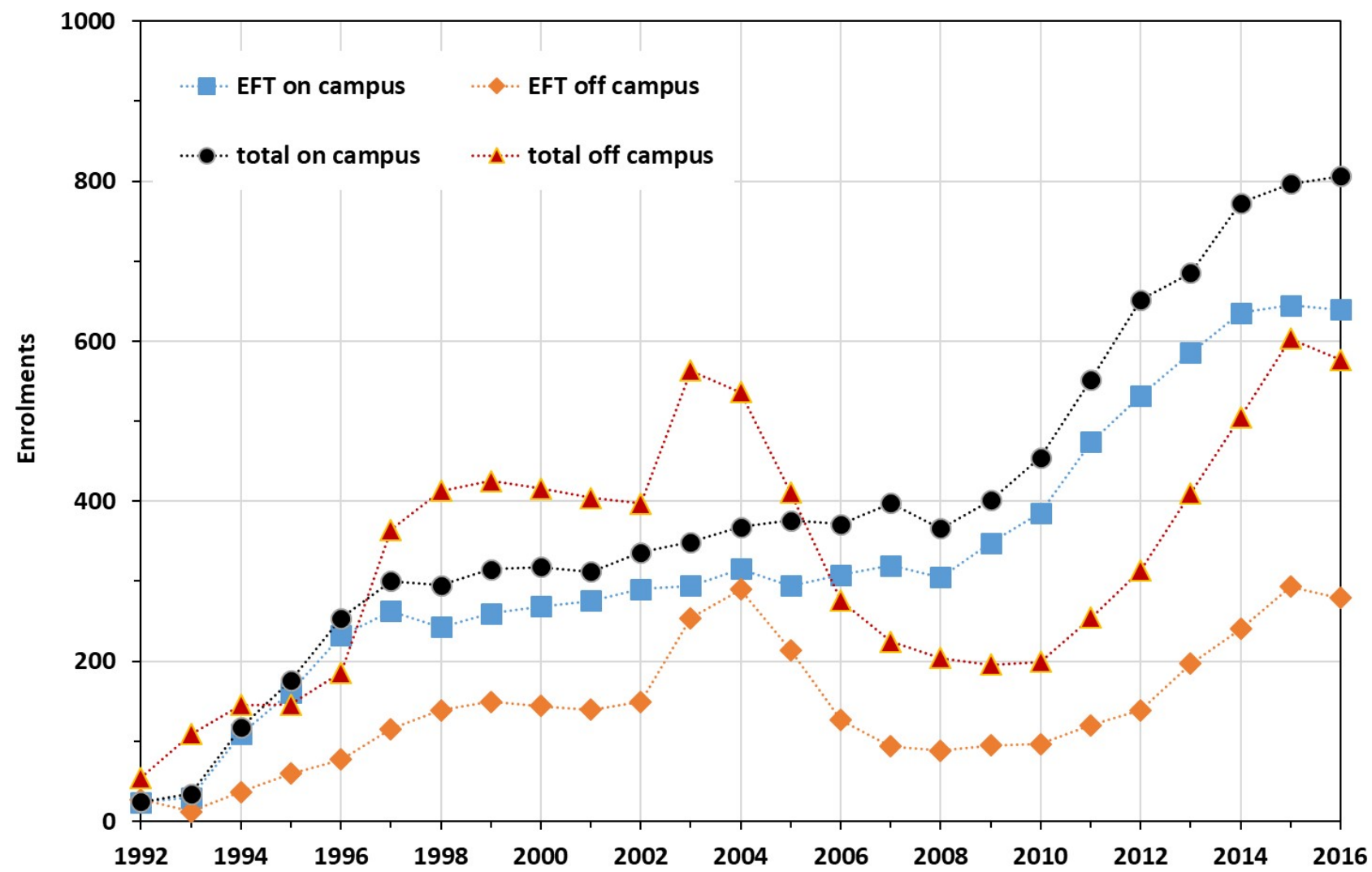

FIG. 7: Undergraduate enrollments for the School of Engineering over the years 1992 -2016. The data for 1992 are from Briggs (1995) and include both the four-year bachelor of engineering and the three-year bachelor of technology programs. The remaining years show the four-year program only. 
financial crisis. The drop in off-campus enrollments after 2004 was in part due to the requirement that these students attend the two-week residential school (Palmer and Bray, 2005). With the exception of a large cohort of students from Malaysia (Selvalingam et al., 2007), many students posted overseas found it too difficult to comply with the residential requirement and thus did not enroll in the program. From 2010 to 2015, both off-campus and on-campus enrollments increased steadily. This was in part due to an increase in the market for students, the university's efforts to increase enrollments overall, and probably a number of socioeconomic and political factors, such as an increase in population around Geelong and the west side of Melbourne (the school's geographic base for students), and government policies toward higher education. It took over ten years for off-campus enrollments to return to their 2004 level. The numbers of students who completed the bachelor of engineering is shown in Fig. 8. Of the total 1713 students who graduated during this time, $31 \%$ were off campus. Since 2000 the number of graduating off-campus students has never been less than 10 percent of the total.

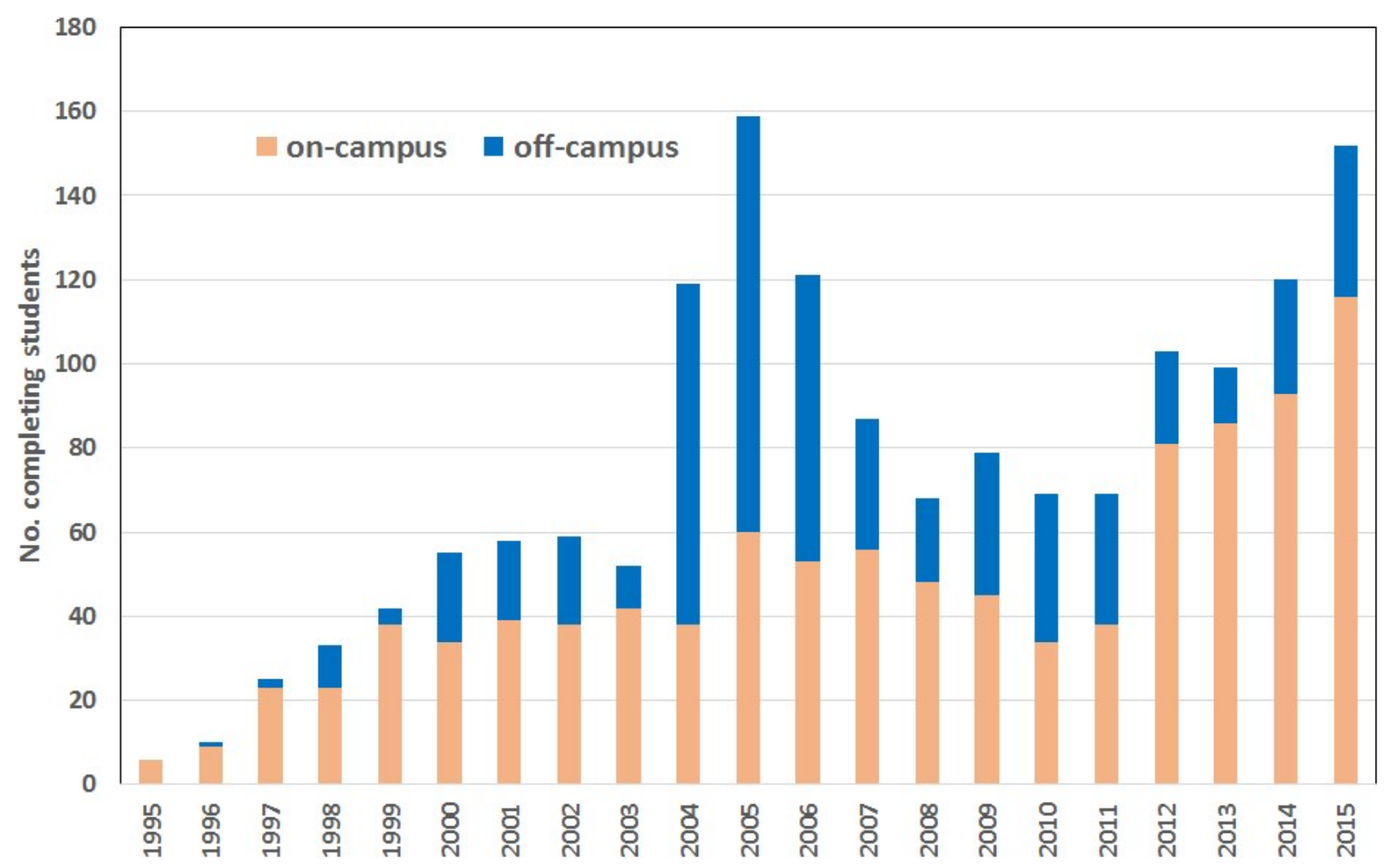

FIG. 8: Raw bachelor-of-engineering graduation data for 1995-2016 


\subsection{Attrition and Completion Times}

Figure 9 shows the attrition rate of both cohorts for the years 2007-2017. On average, the on-campus attrition rate (13\%) was just over half the off-campus attrition rate $(24 \%)$. The grand total shown (17\% overall) is relative to all students in the engineering program. The higher attrition rate for off campus reflects the different circumstances in which the two cohorts generally find themselves. Off-campus students typically have to balance their studies with both work (generally full time) and family (spouses and children). On-campus students, being generally younger, are more often unmarried, without children, and working part-time or not at all.

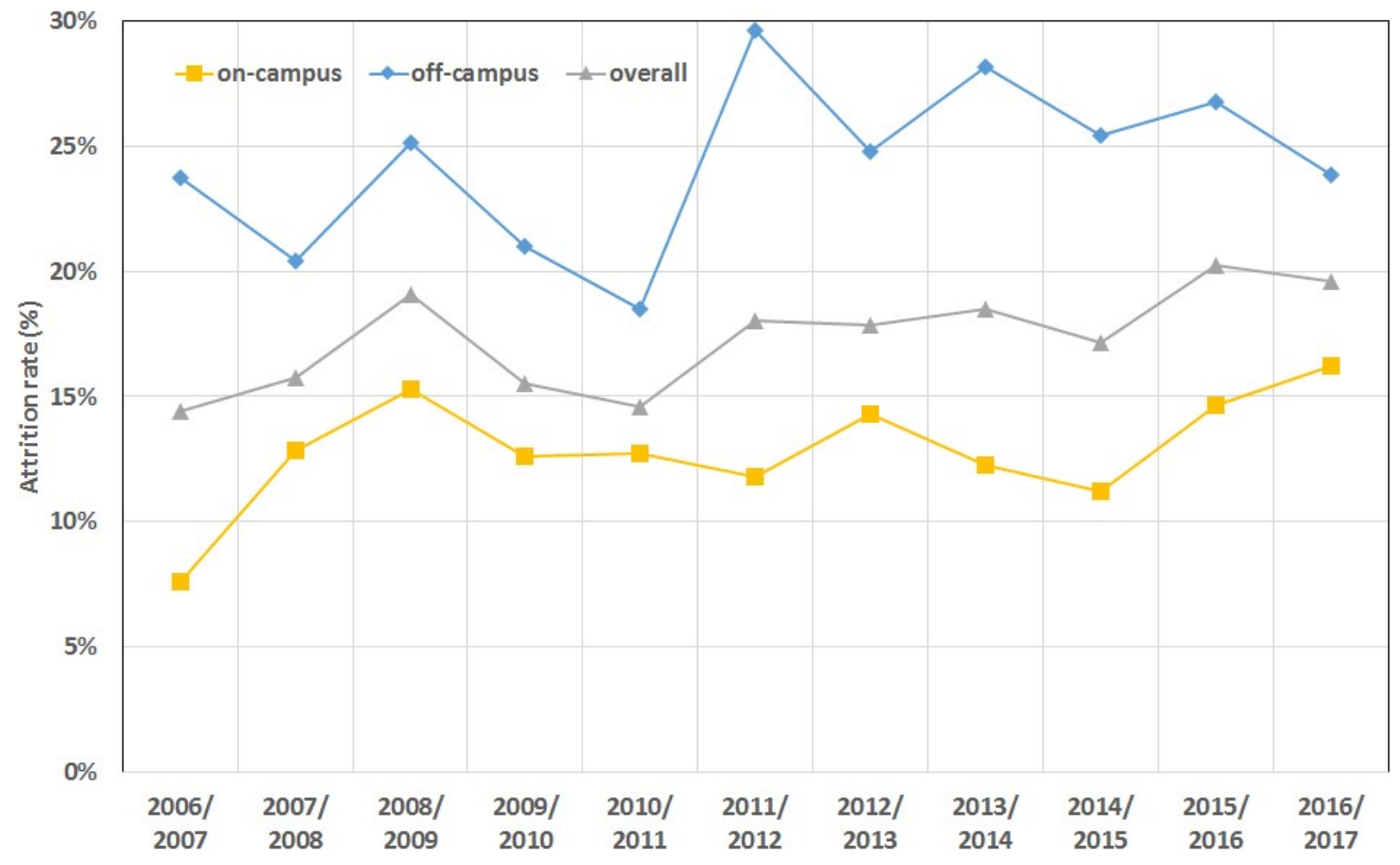

FIG. 9: Attrition rates for 2006-2016

In light of these figures, and keeping in mind that the precise definition of attrition varies widely, the attrition rates of Fig. 9 are comparable with trends observed elsewhere. It is well known that online courses have higher attrition rates than the corresponding oncampus courses, and attrition is a big challenge faced by universities and colleges that offer online learning (Moody, 2004; Murphy and Stewart, 2017; New York Times, 2013) - how much higher across the higher education sector, and engineering in particular, is unclear. Some earlier online courses reported attrition rates as high as $50 \%$. Massive open online courses are known to have attrition rates as high as $90 \%$. A more typical rate 
appears to be $20 \%-25 \%$ (Carr, 2000). In individual online engineering courses, various authors have reported attrition rates as low as $12 \%$ (Orabi, 2005) and as high as $21 \%$ (Dutton et al., 2001). Generally, off-campus attrition rates appear to be about double the corresponding on-campus rate. This is also what was found in an early study of Deakin engineering courses at first and second years (Palmer and Bray, 2002). Palmer's and Bray's study also proposed that among all undergraduate university students, off-campus, mature-age students studying engineering had the greatest likelihood of dropping out completely.

Considering the studies noted here, there is no definite consensus on precisely why the attrition of off-campus students is so much higher than on campus. One might propose that with a several-year gap between studying math at high school and commencing university studies, the more mature, off-campus students are less prepared for the mathematical rigors of an engineering program than their younger, on-campus counterparts. Anecdotal evidence, plus the experience of the author and his colleagues teaching engineering off and on campus for many years, certainly agrees that this is a factor. However, from the evidence cited above, especially the study by Palmer and Bray, it appears that other factors have a larger influence on off-campus attrition. These factors center on an off-campus student balancing the demands of study (usually 20+ hours per week), work, family, and finances.

For the years 2010-2016, Fig. 10 shows how long the average graduating student took to complete the program. When advanced credit is not awarded, the average was 4.8 years for on campus and 6.3 years for off campus. Why average time for on campus is greater than the scheduled four years is likely due to the fact that many of the on-campus students take part-time jobs (Palmer et al., 2008). There is anecdotal evidence to suggest that some on-campus students, on obtaining engineering-related work in their third year of study, change from full-time to part-time study, and this is supported in the data. For both cohorts, many students entered the program with some advanced credit awarded for their previous educational qualifications and work experience. Most off-campus students enter with some advanced credit because they have been in the professional workforce prior to commencing their engineering studies and have prior trade or technical qualifications (Lloyd et al., 1995). For those students who did receive some advanced credit, the average completion times were 3.5 years for on campus and 5.6 years for off campus.

\subsection{Graduate Employment and Program Satisfaction}

Graduate employment is shown in Fig. 11. The percentage of employed off-campus graduates (93\% overall) was always higher than that of on-campus graduates $(73 \%)$, and was over $90 \%$ for 11 of the 13 years surveyed. This is not surprising given the nature of 


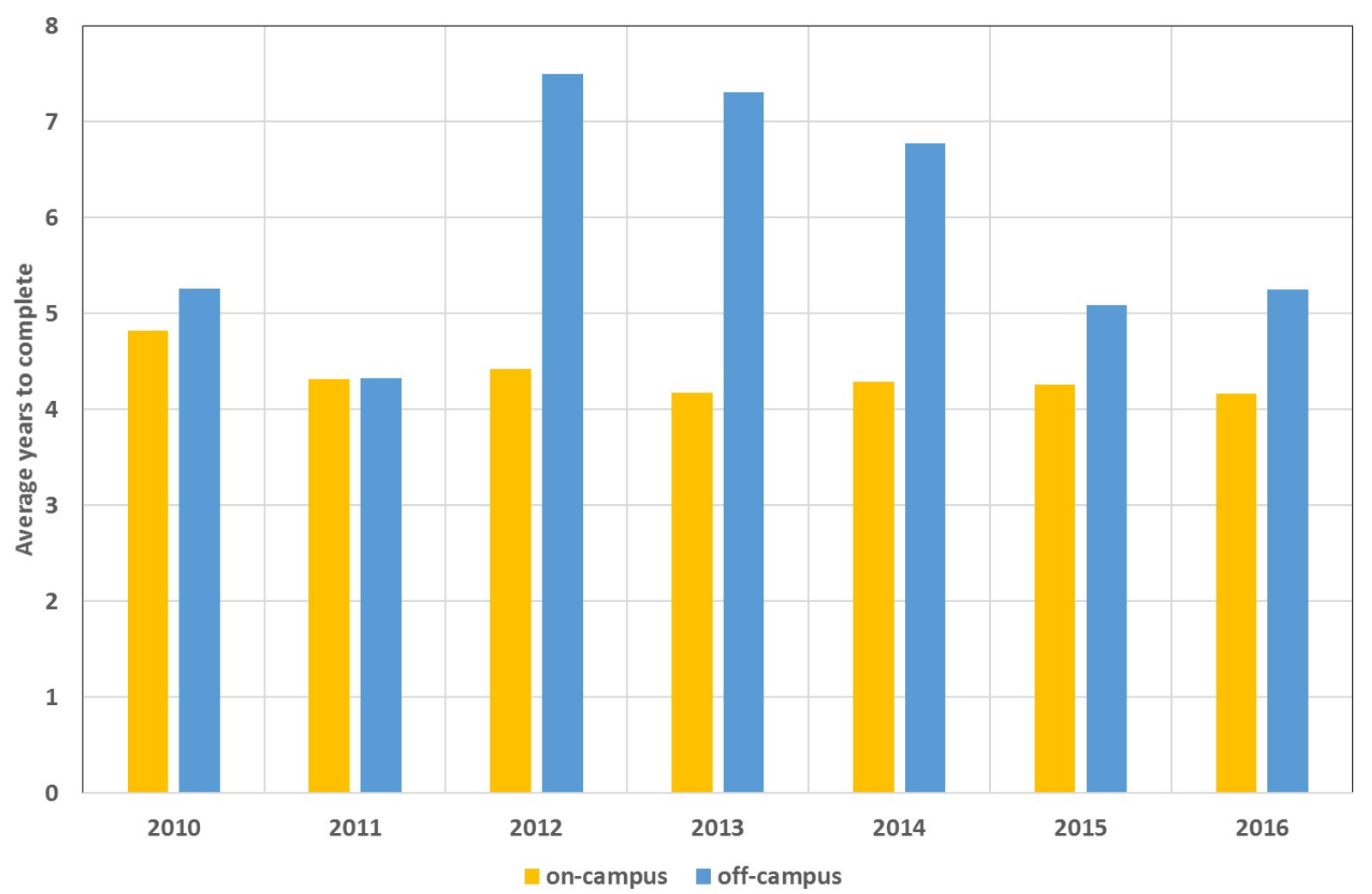

FIG. 10: Average student completions times for 2010-2016

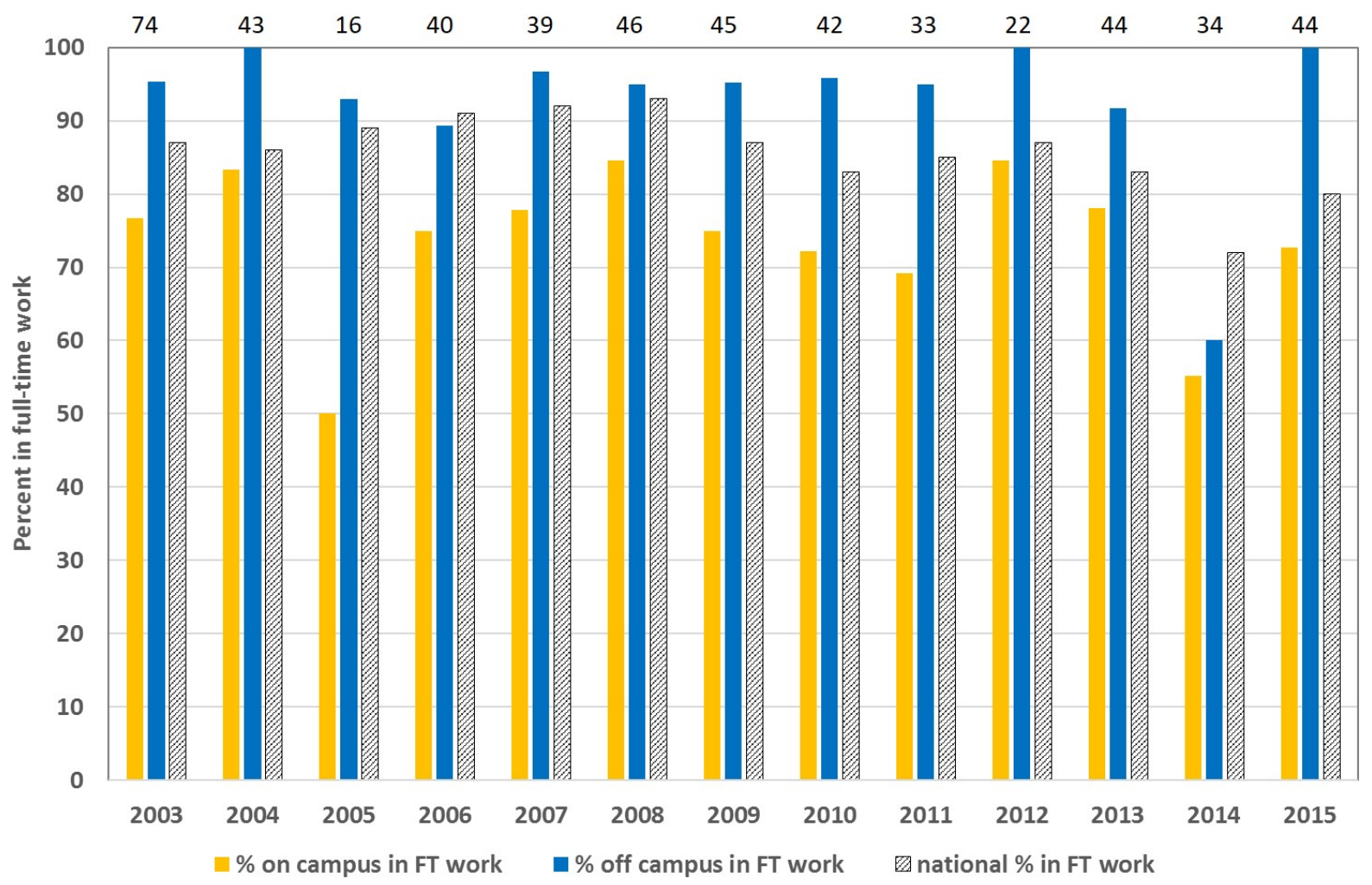

FIG. 11: Graduate employment data as a percentage of the total for 2003-2015. The total number of responses from Deakin are shown across the top. 
the cohorts. Most on-campus graduates, being in general the younger cohort, are starting their first full-time job in engineering. The off-campus students tend to already be employed full time when they start their degree and continue to be employed after graduation. Also, not surprisingly, the overall graduate employment rate for off-campus graduates was higher than the national rate $(86 \%)$. Nationally, the majority of engineering graduates would be seeking or starting out on their first full-time professional job.

Figures 12 and 13 show comparative student satisfaction for the years 2003-2015. On the good-teaching scale, off-campus students rated the program lower than the on-campus students ( $40 \%$ overall as compared with $49 \%$ ), and the off-campus scores were on average below the national scores ( $47 \%$ overall). On the other hand, in the overallsatisfaction score, one observes quite the opposite. On average, the off-campus students showed ten percentage points greater satisfaction with the program than did the oncampus students. Also, overall, the off-campus score $(80 \%)$ was eight percentage points higher than the national score $(72 \%)$. The key difference between the on-campus and off-campus programs is that on-campus students attend regular classes face to face with their professors and instructors and the off-campus students do not. The results seem to

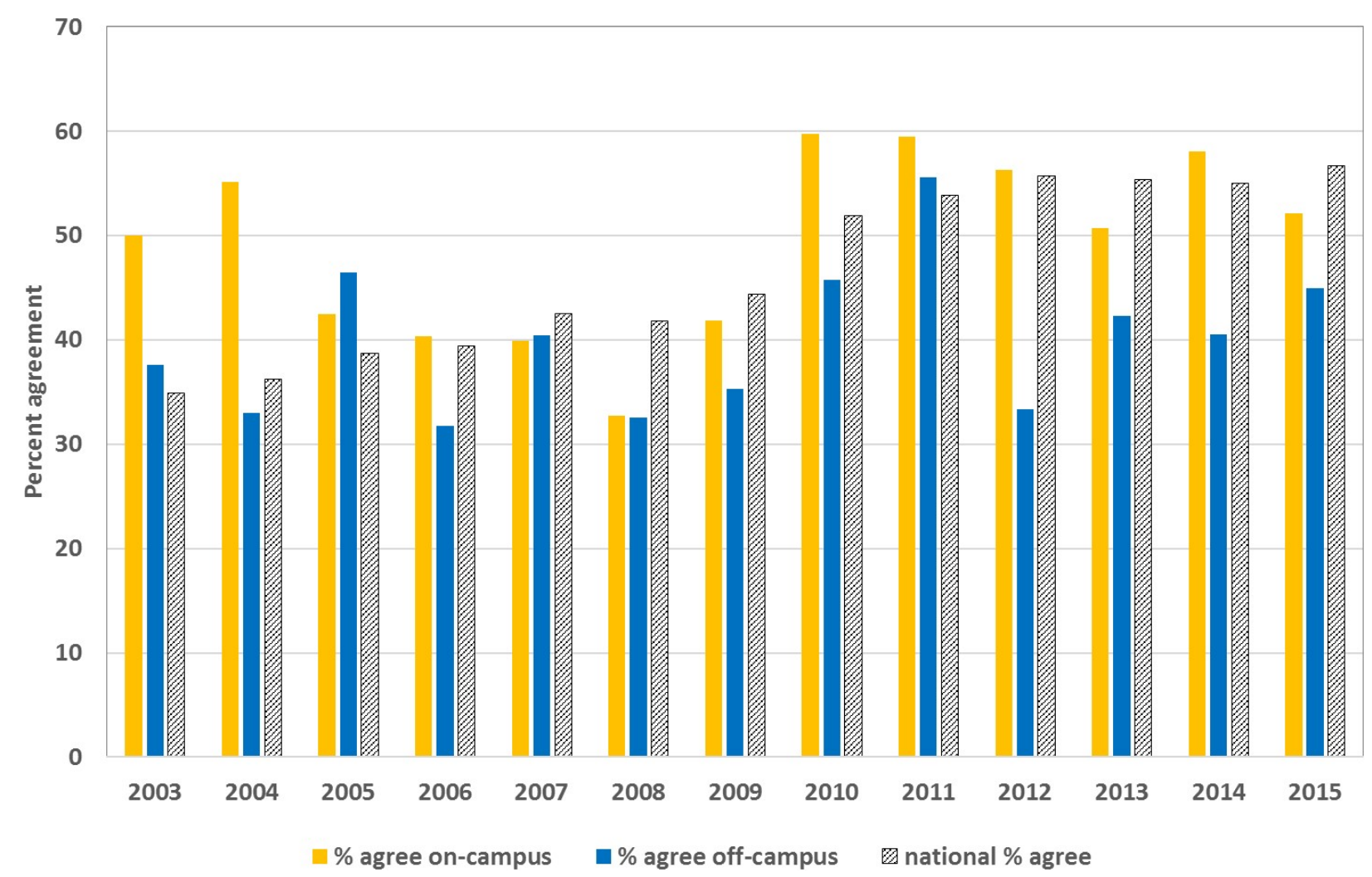

FIG. 12: Responses to the statements posed in the CEQ good-teaching scale from 2003 to 2015 


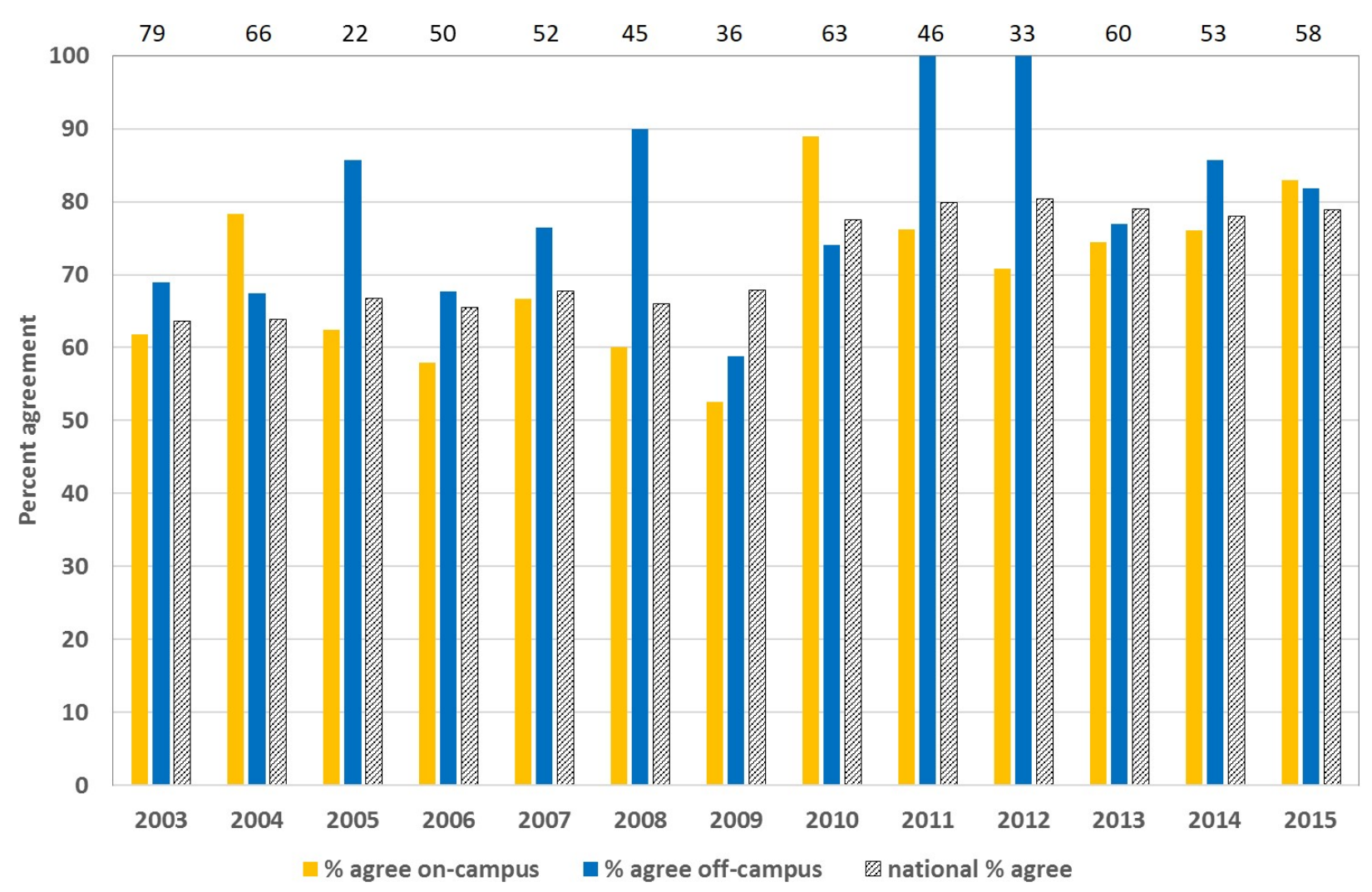

FIG. 13: Responses from 2003 to 2015 to the statements posed in the CEQ statement, "Overall, I was satisfied with the quality of this (program)." The total number of responses from Deakin are shown across the top.

suggest that off-campus students consider face-to-face teaching to be the superior mode of teaching, in spite of advances in the educational technology used to deliver teaching off campus, especially the use of video-recorded lectures and tutorials. However, the overallsatisfaction scores might suggest that off-campus students are aware of the limitations distance education has as compared with traditional on-campus education. They know and accept what they are getting into.

\section{DISCUSSION}

In addition to high-quality teaching staff, texts and teaching materials, and administration, it has been found that there are other important factors that contribute to the success of an off-campus program in undergraduate engineering and its appeal to potential students. The university has established significant educational infrastructure to support online and distance learning.

The programs are offered both on and off campus, and there is no distinction between the two. Since online degrees are still relatively new, having an identical on-campus program and one degree increases the credibility of the off-campus program in the mind of a 
potential student. The degree is fully accredited and fulfills the requirements set by the Washington Accord. Thus students completing the degree qualify as graduate engineers, both locally and overseas. Tuition fees are the same for on campus and off campus. The school has a vibrant research program that adds value to the undergraduate courses. Offcampus students are encouraged to select projects from within their place of employment, which very often is engineering in nature. Online teaching materials produced with off campus in mind are also available to on-campus students. In an attempt to flip the oncampus classroom in a first-year physics course, the task was much easier because the online study guides and most of the video content were already available (Long, 2015).

\subsection{Graduate Employability}

The graduate employment results of Fig. 11 might suggest that the employability of graduates in online programs is as good as, or higher, than those graduating from oncampus programs. One must be very careful in making these sorts of comparisons, because the two cohorts are quite different in terms of age, maturity, and prior work experience. While recent Australian studies have shown that many engineering students are quite concerned about obtaining employment after graduation (Thirunavukarasu et al., 2020) and that across Australia, a majority of engineering graduates work in nonengineering roles (Palmer et al., 2015), studies of employment trends of engineering graduates from online programs are quite scant. The available data does not distinguish among types of jobs the respondents have. This being said, because they are normally older and have professional jobs, most off-campus students have interesting work experience and stories to tell that enrich the educational experience for their fellow students, especially the younger on-campus ones.

\subsection{Further Work}

This paper presents a great deal of data on the performance of the school's efforts to bring engineering education to an off-campus student community. It is the author's purpose to present a first look, an overview of a successful off-campus engineering program, and to present some data to support the assertion that the school's efforts have been worthwhile. Further work would include a statistical analysis of all the numerical comparisons made here, off campus versus on campus, and off campus versus national averages. An example is a very recent longitudinal study of off-campus versus on-campus academic performance in the first-year course SEP101, Engineering Physics. An analysis of 20 years of academic grades in this course revealed no statistically significant difference between final grades off campus versus on campus (Poudel, 2018).

Published studies from the school discussing development and evaluation of pedagogies for off-campus teaching of engineering have been limited mainly to mechatronics 
(Joordens), engineering management (Palmer), and physics (Long). There are many other education innovations and initiatives yet to study. One obvious study not done yet is an evaluation of teaching engineering mathematics to off-campus students. Other fields that come to mind are the other majors in the bachelor of engineering (mechanical, electrical, and civil). The rapid development of technology and how that affects pedagogies for online education, and how students use them, is also a subject for further study. And, of course, there are many others, such as innovative techniques for at-home experimentation.

\subsection{The Future}

Looking to the future, Deakin's School of Engineering is currently heading down a new path that will affect the nature of its programs and off-campus teaching. All engineering majors have been completely redeveloped to implement a collaborative, design-led approach to teaching across all four years. First introduced in 1997 (Joordens and Jones, 1998), project-based learning has been practiced for many years in the mechatronics major (Chandrasekaran et al., 2015). In 2016, the school introduced a new curriculum called "Project-Oriented Design-Based Learning" (PODBL), where student learning centers on groups working together to solve design problems, learning the necessary engineering concepts and skills along the way (Chandrasekaran et al., 2013). In its implementation across all majors, the number of project and design components has increased across from about $25 \%$ to $50 \%$ of the educational content.

The PODBL curriculum is one aspect of a wider project to establish the Deakin Center for Advanced Design in Engineering Training (CADET), a new center for engineering education across all years, primary school all the way to doctorate (Littlefair and Stojcevski, 2012). CADET was founded on three key pillars of innovative engineering education, recruiting engineering students through a series of extensive outreach activities (Long et al., 2017a) and fostering industry engagement through industrial research projects. Inspiration for CADET included the Singapore University of Technology, Aalborg University in Denmark, and Olin College in the United States.

A case in point is Olin College. Olin was established because of a perceived need to significantly change how engineers are trained in North America (Miller and Dorning, 2018). Central to its curriculum are hands-on design projects at all year levels, teamwork, and community outreach. The mission of CADET and its new PODBL curriculum follows similar principles and applies them to both on-campus and off-campus cohorts. One difference between the two, typical of Australian universities, is that in Australia engineering studies are very focused from the first year. Subjects designed to give students breadth, such as English and history, are typically delivered in high school. 
PODBL runs both on and off campus (Maung-Than-Oo et al., 2014). Again, the curriculum is identical for both cohorts except in how classes are given. Students are arranged in groups, and each group has a mix of on-campus and off-campus students. The groups meet in person during the individual courses' intensive days. Initial assessments of the new curriculum indicate that the off-campus cohort is generally satisfied with the new curriculum, and the academic performance of both cohorts is similar (Long et al., 2016a, 2017b, 2018). The new curriculum is still relatively new. Further studies will help determine its long-term effectiveness.

Other new educational technologies being considered for the future include further use of adaptive tutoring systems, more remote-controlled lab experiments, a redevelopment of lab kits for teaching mechatronics, the development of an Arduino-based kit for physics experiments, the use of sensors and apps on cell phones also for physics experiments, and lecturer-created videos (as opposed to more expensive studio recording and editing) for delivering primary engineering content. In the longer term, virtual and augmented reality could be used as educational platforms.

\subsection{Lessons for the Educator}

As noted earlier, a significant amount of educational infrastructure is necessary to effectively deliver an engineering program online. This, of course, applies to any online education program. Of this infrastructure, what might be unique to Deakin (and other online education providers in Australia) is the ability to ship library materials to students scattered about the region and to deliver exams to students anywhere in the world. When an online course has an exam, all the students take the exam at designated local, supervised examination centers.

This author finds it puzzling that the vast majority of online undergraduate engineering courses one finds in the literature are in the field of electrical engineering. Most of these use modern educational technologies such as video classes, learning-management systems, remote lab demonstrations, and experimental kits (Berry, 2015; Phillips and Saraniti, 2016; Scott et al., 2012). Most universities have systems in place that could be adapted to deliver online programs. Most textbooks have accompanying websites (Pearson's Mastering Engineering is one), with resources that could be easily adapted to online courses. Furthermore, with the availability of educational innovations such as remote labs, web-conferencing, e-books, and other technologies employed here, the reasons why engineering schools choose not to offer online programs are dwindling.

Deakin's long experience shows that many engineering programs can be offered online. Although he hesitates to agree with the proposed obsolescence of undergraduate laboratories (Cancilla and Albon, 2017), in the author's opinion, most, if not all, lab 
experiences required for the first two years of an engineering program can be accomplished at a distance, electrical and mechatronics being the easiest and civil being the hardest. A proper evaluation of this hypothesis is another study for another day. But without a doubt how students learn is changing, and now a student has access to whole libraries (and indeed, measurement laboratories) in the pocket-sized cell phone. Fewer and fewer young people learn by attending on-campus classes or reading books. Institutional education is struggling to keep up.

The pedagogies shown here are equally applicable to students anywhere else in the world. Due to its larger population, the problem of students being physically isolated from the university is not nearly as acute in for instance, the United States as it is in Australia. But in the USA, there is still much potential for extending engineering education to students who for the various reasons mentioned earlier are unable to attend on-campus classes. One obvious example is that of military personnel who are posted either overseas or in remote bases, far from a student's home. With an appropriate program, a soldier serving at a base in, for instance, Germany, or a sailor at sea could undertake engineering training, which would assist the student later with transitioning to a civilian career.

\section{CONCLUSION}

In 2005, Bourne and colleagues called for engineering education "anywhere, anytime." Fifteen years later, in spite of numerous individual online courses in engineering being offered, complete online baccalaureate engineering programs are still rare. Deakin University in Australia is one institution that for over 25 years has offered a fully accredited bachelor of engineering by distance education/online learning, with robust enrollments. It has kept abreast of modern communications technologies, development trends in education, and the constantly changing nature of student cohorts. Many universities and colleges put online engineering studies in the too-hard basket. It is hoped that the case presented here helps to dispel the myth that online programs in undergraduate engineering cannot be done or are not worth the effort.

\section{ACKNOWLEDGMENTS}

The author wishes to express his gratitude to P. Gladigau, B. Guthrie, and W. Marchment for their assistance in obtaining the data for this manuscript. He thanks L.D. Krute from North Carolina State University for many informative discussions on engineering distance education in the United States. He also is deeply indebted to the early heads of the Deakin University School of Engineering, L.R. Baker, P.D. Hodgson, and K. Baskaran, and to two other pioneers of the school, N. Miller and D. LeGrew. 


\section{REFERENCES}

ABET, Online Program Accreditation, accessed February 10, 2020, from http://www.abet.org/accreditation/find-programs/, 2020.

ABET Industry Advisory Council, Distance Education. Viewpoints, 1, accessed from http://www.abet.org/wp-content/uploads/2015/05/Viewpoints_Vol1.pdf, 2000.

Ashton, J., School of the Air, Adelaide: Rigby, 1978.

Bagheri, M.M., Intelligent and Adaptive Tutoring Systems: How to Integrate Learners, Int. J. Ed., vol. 7, no. 2, pp. 1-16, 2015.

Berry, C.A., Teaching an Electrical Circuits Course Online, Proc. of the 2015 ASEE Annual Conf. and Exposition, Seattle, WA, pp. 26.1464.1-16, 2015.

Birdwell, J.A. and Peshkin, M., Capturing Technical Lectures on Lightboard, Proc. of the 2015 ASEE Annual Conference and Exposition, Seattle, WA, pp. 26.325.1-9, June 14-17, 2015.

Blackboard Inc., Blackboard Collaborate, accessed February 10, 2020, from https://www.blackboard.com/teaching-learning/collaboration-web-conferencing/blackboardcollaborate, 2020.

Bourne, J., Harris, D., and Mayadas, F., Online Engineering Education: Learning Anywhere, Anytime, J. Eng. Ed., vol. 94, no. 1, pp. 131-146, 2005.

Bradley, A., Engineers Australia Policy on Accreditation of Programs Offered in Distance Mode, Canberra: Engineers Australia, 2007.

Briggs, H., Towards Student-Centred Engineering Education at Deakin University: A Case Study in Implementing Flexible Learning Philosophies, in Distance Education: Crossing Frontiers, F. Nouwens, Ed., Rockhampton, QLD: Central Queensland University, 1995.

Briggs, H. and Hodgson, P., The Changing Culture and Practice of Undergraduate Engineering Education in Australia, Brit. J. Eng. Ed., vol. 1, no. 2, pp. 31-42, 2000.

Buechler, D.N., Sealy Jr., P.J., and Goomey, J., Three Pilot Studies with a Focus on Asynchronous Distance Education, Proc. of the 2014 American Society for Engineering Education Annual Conf. and Exposition, Indianapolis, IN, pp. 24.1262.1-20, June 15-18, 2014.

Cancilla, D.A. and Albon, S.P., Should We Continue to Provide Life Support to the Traditional Undergraduate Teaching Laboratory or Is It Time to Let It Go? Int. J. Innov. Online Ed., vol. 1, no. 2, pp. 28-31, 2017.

Carr, S., As Distance Education Comes of Age, The Challenge Is Keeping the Students, Chron. Higher Ed., vol. 46, no. 23, pp. A39-A41, 2000. 
Chandrasekaran, S., Long, J.M., and Joordens, M.A., Evaluation of Student Learning Outcomes in Fourth Year Engineering Mechatronics through Design Based Learning Curriculum, in 2015 IEEE Frontiers in Education Conf. Proc., Piscataway, NJ, pp. 2217 $-2223,2015$.

Chandrasekaran, S., Stojcevski, A., Littlefair, G., and Joordens, M., Project-Oriented Design-Based Learning: Aligning Students' Views with Industry Needs, Int. J. Eng. Ed., vol. 29, no. 5, pp. 1109-1118, 2013.

Cleveland-Innes, M.F. and Garrison, D.R., Eds., An Introduction to Distance Education: Understanding Teaching and Learning in a New Era, New York: Routledge, 2010.

Coldwell, J., Craig, A., Paterson, T., and Mustard, J., Online Students: Relationships between Participation, Demographics and Academic Performance, Elect. J. e-Learning, vol. 6, no. 1, pp. 19-30, 2008.

Dawkins, J.S., Higher Education: A Policy Statement, Canberra: Australian Government, 1988.

Deakin University, Bachelor of Information Technology, accessed February 10, 2020, from http://www.deakin.edu.au/course/bachelor-information-technology/, 2020.

Dong, C. and Goh, P.S., Twelve Tips for the Effective Use of Videos in Medical Education, Med. Teacher, vol. 37, no. 2, pp. 140-145, 2015.

Dutton, J., Dutton, M., and Perry, J., Do Online Students Perform as Well as Lecture Students? J. Eng. Ed., vol. 90, no. 1, pp. 131-136, 2001.

Echo360, The Easiest, Most Reliable Lecture Capture Solution at Any Scale, accessed January 15, 2020, from https://echo360.com/lecturecapture/, 2020.

Engineers Australia, Stage 1 Competency Standard for Professional Engineer, accessed 15 January 2020, from https://www.engineersaustralia.org.au/resource-centre/resource/ stage-1-competency-standard-professional-engineer/, 2017.

Engineers Australia, Accreditation of Engineering Education Programs, accessed January 15, 2020, from https://www.engineersaustralia.org.au/About-Us/Accreditation/, 2020.

Feisel, L.D. and Rosa, A.J., The Role of the Laboratory in Undergraduate Engineering Education, J. Eng. Ed., vol. 94, pp. 121-130, 2005.

Ferguson, C., The Continuous Professional Development of Engineers and Flexible Learning Strategies, Int. J. Lifelong Ed., vol. 17, no. 3, pp. 173-183, 1998.

Hains-Wesson, R., McKenzie, S., and Bangay, S., Anytime and Anywhere: A Case Study for Blended Learning, EDUCAUSE Rev., accessed from https://er.educause.edu/articles/2015/ 7/anytime-and-anywhere-a-case-study-for-blendedlearning, 2015. 
Hall, W., Jones, J.T., and Palmer, S., Providing a Practical Education for Off-Campus Engineering Students, Brit. J. Eng. Ed., vol. 5, no. 1, pp. 49-57, 2006.

Hall, W., Palmer, S., Ferguson, C., and Jones, T., Delivery and Assessment Strategies to Improve On- and Off-Campus Student Performance in Structural Mechanics, Int. J. Mech. Eng. Ed., vol. 35, no. 4, pp. 272-284, 2007.

Harris, K.L. and James, R., The Course Experience Questionnaire, Graduate Destination Survey, and Learning and Teaching Performance Fund in Australia, in Public Policy for Academic Quality: Analyses of Innovative Policy Instruments, D.D. Dill and M. Beerkens, Eds., Dordrecht: Springer, pp. 99-119, 2010.

Herrmann, H., Cameron, J., and Davidson, G., On-Campus Requirements in Remote Area Australian Distance Education, Open Learning, vol. 6, no. 2, pp. 21-27, 1991.

Holt, D. and Palmer, S., Quality in Flexible, Online and Distance Education at Deakin University, Australia, in Total Quality Management of Distance Education, N. Padhi, Ed., New Delhi: Atlantic, pp. 203-214, 2010.

Horn, A. and Owen, S., Deakin University Library: An Active Partner in the Implementation of the New Generation E-Learning Platform Desire2learn, Proc. of the IATUL: 32nd Intl. Assocation of Scientific and Technological University Libraries Conf., Warsaw, Poland, May 31-June 2, 2010.

Hughes, J.L.A. and Frost, J.D., Gtrep: A New Model for Expanding the Availability of Engineering Education, Proc. of the 31st ASEE/IEEE Frontiers in Education Conf., Reno, NV, vol. 3, pp. F4B-1-6, 2001.

International Engineering Alliance, The Washington Accord, accessed February 10, 2020, from https://www.ieagreements.org/accords/washington/, 2020.

Jevons, J., Distance Education in Mixed Institutions: Working Towards Parity, Distance Ed., vol. 5, no. 1, pp. 24-37, 1984.

Jones, J.T. and Joordens, M., Distance Learning for Laboratory Practical Work in Microcontrollers, Int. J. Eng. Ed., vol. 19, no. 3, pp. 455-459, 2003.

Joordens, M., Programmable Logic Controller Simulator for Distance Education, Proc. of the 10th Annual Convention and Conf. of the Australasian Association for Engineering Education, Gladstone, Queensland, Australia, September 28-30, 1998.

Joordens, M., Problem Based Learning Via an Interactive Game, Proc. of the IACEE World Conf. on Continuing Engineering Education, Valencia, Spain, May 17-19, 2012.

Joordens, M., Teaching with a Tablet PC, Int. J. Quality Assur. Eng. Technol. Ed., vol. 5, no. 3, pp. 1-14, 2016. 
Joordens, M. and Jones, J.T., Multi-Disciplinary Design-and-Build Projects in Mechatronic Engineering Degree Courses, Proc. of the 11th Australasian Conf. on Engineering Education, Adelaide, Australia, September 26-29, 1998.

Kilicay-Ergin, N. and Laplante, P.A., An Online Graduate Requirements Engineering Course, IEEE Transact. Ed., vol. 56, no. 2, pp. 208-216, 2013.

Krute, L., Keltie, R.F., Lavelle, J.P., Meno, M., and Fortney, W.B., Distance Education Partnerships, Proc. of the 2012 ASEE Annual Conf., San Antonio, TX, June 10-13, 2012.

Lal, S., Lucey, A.D., Lindsay, E., Treagust, D.F., Mocerino, M., Long, J.M., et al., The Effects of Remote Laboratory Implementation on Freshman Engineering Students' Experience, Proc. of the 2018 ASEE Annual Conf. and Exposition, Salt Lake City, UT, 2018.

Leigh, L., Sydney Startup Smart Sparrow Partners with Deakin University to Enhance Online Education, Startupdaily, accessed from https://www.startupdaily.net/2016/08/smartsparrow-deakin-university/, 2016.

Lemckert, C. and Florance, J., Real-Time Internet Mediated Laboratory Experiments for Distance Education Students, Brit. J. Ed. Technol., vol. 33, no. 1, pp. 99-102, 2002.

Lipnicki, J., Ed., The Good Universities Guide 2019, Melbourne: Good Education Group, 2018.

Littlefair, G. and Stojcevski, A., CADET - Centre for Advanced Design in Engineering Training, Proc. of the 23rd Annual Conf. of the Australian Association for Engineering Education, Melbourne, Australia, December 3-5, 2012.

Lloyd, B., Briggs, H., and Baker, L., A Student-Centred Framework for Recognition of Prior Learning in Engineering Education, in Proc. of the Int. Congress of Engineering Deans and Industry Leaders, Z.J. Pudlowski and P.L.P. Darvall, Eds., Melbourne: Monash University, pp. 464-469,1995.

Lloyd, B.E., Ferguson, C., Palmer, S., and Rice, M.R., Engineering the Future: Preparing Professional Engineers for the 21st Century, Melbourne: Histec Publications, 2001.

Long, J.M., Cloud-Based Teaching in an Engineering-Physics Course, 2015 IEEE Frontiers in Education Conf. Proc., Piscataway, NJ: IEEE, pp. 1832-1839, 2015.

Long, J.M., Cavenett, S.W., Gordon, E., and Joordens, M., Enhancing Learning for Distance Students in an Undergraduate Engineering Course through Real-Time WebConferencing, Proc. of the 2014 ASEE Int. Forum, Indianapolis, IN, June 14, 2014a.

Long, J.M., Chandrasekaran, S., and Orwa, J.O., Engineering Fundamentals in a New Undergraduate Curriculum, in Proc. of the 27th Annual Conf. of the Australasian Association for Engineering Education, S.T. Smith, Y.Y. Lim, A. Bahadori, N. Lake, R.V. Padilla, A. Rose, and K. Doust, Eds., Lismore: Southern Cross University, 2016a. 
Long, J.M., Chandrasekaran, S., and Cavenett, S.W., Freshman Residential Schools for Undergraduate On-Campus and Online Engineering Students, Proc. of the 2016 ASEE Annual Conf. and Exposition, New Orleans, LA, 2016b.

Long, J.M., Collins, L., Steinwedel, J., Sautner, J., and Cavenett, S., Fast-Cars in Schools: A Cadet Outreach Initiative, in Proc. of the 28th Annual Conf. of the Australasian Association for Engineering Education, N. Huda, D. Inglis, N. Tse, and G. Town, Eds., Sydney: Macquarie University, pp. 948-954, 2017a.

Long, J.M. and Hartas, K.J., An AC Signal-Generator and PC-Oscilloscope Test Package for Distance Students in Undergraduate Electronics, Proc. of the 2005 ASEE/AAEE 4th Global Colloquium on Engineering Education, D. Radcliffe and J. Humphries, Eds., Sydney: Australasian Association for Engineering Education, 2005.

Long, J.M., Pereira, M., and Chandrasekaran, S., Implementation of Project-Oriented Design-Based Learning in a Second-Year Mechanical/Mechatronics Subject, Proc. of the 28th Annual Conf. of the Australasian Association for Engineering Education, N. Huda, D. Inglis, N. Tse, and G. Town, Eds., Sydney: Macquarie University, pp. 963-973, 2017b.

Long, J.M. and Baskaran, K., Engineering Education Down Under: Distance Teaching at Deakin University, Australia, Proc. of the 2004 ASEE Annual Conf. and Exposition, Salt Lake City, UT, 2004.

Long, J.M., Chenery, K.L., Stannard, W.B., and Fitzgerald, K.J., Use of Web-Conferencing Software to Enhance Practical Learning for Distance Students in a First-Year Engineering Course, Proc. of the 24th Annual Conf. of the Australasian Association for Engineering Education, Gold Coast, Queensland, Australia, 2013.

Long, J.M., Horan, B.P., and Hall, R.H., Undergraduate Electronics Students' Use of Home Experiment Kits for Distance Education, Proc. of the 2012 ASEE Annual Conf., San Antonio, TX, June 10-13, 2012.

Long, J.M., Kaynak, A., Paulino, M., and Chandrasekaran, S., Online and Design-Based Learning in Sophomore Engineering Mechanics, Int. J. Innov. Online Ed., vol. 2, no. 3, 2018.

Long, J.M., Stannard, W.B., Chenery, K., and Joordens, M.A., Physics Practicals for Distance Education in an Undergraduate Engineering Course, Proc. of the 2012 Australasian Association for Engineering Education Conf., Melbourne, Australia, 2012. Long, J.M., Thomas, S.K., Campbell, A.M.V., Crawford, T., Sian, R.K., Stannard, W.B., et al., Video Presentations in Engineering-Physics Practicals to Increase the Efficiency of Teaching and Learning, Proc. of the 25th Annual Conf. of the Australasian Association for Engineering Education, Wellington, New Zealand, 2014b. 
Lyons, L., Enhancing Engineering Education through Remote Laboratories, PhD, Deakin University, Geelong, 2017.

Maung-Than-Oo, A., Chandran, J., and Stojcevski, A., Technology Adoption in Engineering Design for Distance Education, Int. J. Quality Assur. Eng. Technol. Ed., vol. 3, no. 2, pp. 54-64, 2014.

Mayadas, A.F., Bourne, J., and Bacsich, P., Online Education Today, Science, vol. 323, no. 1, pp. 85-89, 2009.

McKnight, S., Changing the Mindset: From Traditional On-Campus and Distance Education to Online Teaching and Learning, in E-Learning and Digital Publishing, H.S. Ching, P.W.T. Poon, and C. McNaught, Eds., Dordrecht: Springer, 2006.

McMurtrie, B., Controversy at George Washington Univ. Highlights Challenges of Diving Deeply into Online Education, Chronicle of Higher Education, accessed from https://www.chronicle.com/article/Controversy-at-George/241528, 2017.

Miller, R.K. and Dorning, A.M., Olin College of Engineering: Reinventing Engineering Education in the United States, in Accelerated Universities: Ideas and Money Combine to Build Academic Excellence, P.G. Altbach, L. Reisberg, J. Salmi, and I. Froumin, Eds., Boston: Brill Sense, 2018.

Moody, J., Distance Education: Why Are the Attrition Rates So High? Quart. Rev. Distance Ed., vol. 5, no. 3, pp. 205-210, 2004.

Morgan, M.J., Fulcher, R.L., and Ku, H.S., Innovative Residential Schools for Engineering Degree Courses, Quart. J. Singapore Inst. Eng. Technol., vol. 18, no. 4, p. 53, 1999.

Murphy, C.A. and Stewart, J.C., On-Campus Students Taking Online Courses: Factors Associated with Unsuccessful Course Completion, Internet Higher Ed., vol. 34, pp. 1-9, 2017.

New York Times, The Trouble with Online College, The New York Times, p. A22, 2013.

Orabi, I.I., Teaching an Engineering Course Online Using Blackboard, Proc. of the 2005 ASEE Annual Conf. and Exposition, pp. 10.437.1-15, 2005.

Palmer, S., Authenticity in Assessment: Reflecting Undergraduate Study and Professional Practice, Eur. J. Eng. Ed., vol. 29, no. 2, pp. 193-202, 2004.

Palmer, S., An Evaluation of On-Line Assignment Submission, Marking and Return, J. Ed. Technol. Syst., vol. 34, no. 1, pp. 57-67, 2005.

Palmer, S., An Evaluation of Streaming Digital Video Resources in On- and Off-Campus Engineering Management Education, Comput. Ed., vol. 49, no. 2, pp. 297-308, 2007.

Palmer, S., The Lived Experience of Flexible Education: Theory, Policy and Practice, J. Univ. Teaching Learning Practice, vol. 8, no. 3, pp. 1-16, 2011. 
Palmer, S., The Performance of a Student Evaluation of Teaching System, Assess. Eval. Higher Ed., vol. 37, no. 8, pp. 975-985, 2012a.

Palmer, S., Understanding the Context of Distance Students: Differences in On- and OffCampus Engagement with an Online Learning Environment, J. Open, Flexible Distance Learning, vol. 16, no. 1, pp. 70-82, 2012b.

Palmer, S. and Bray, S., Assessing the Likely Impact of Mandatory Residential Sessions for Engineering and Technology Students, Proc. of the 2005 ASEE/AAEE 4th Global Colloquium on Engineering Education, Sydney, Australia, 2005.

Palmer, S., Bray, S., and Hall, W., What Is the On-Campus Experience? Engineering Student Study and Work, Int. J. Eng. Ed., vol. 24, no. 4, pp. 802-810, 2008.

Palmer, S. and Bray, S.L., On- and Off-Campus Student Persistence and Academic Performance, Eng. Sci. Ed. J., vol. 11, no. 2, pp. 66-72, 2002.

Palmer, S. and Ferguson, C., Improving Outcomes-Based Engineering Education in Australia, Aust. J. Eng. Ed., vol. 14, no. 2, pp. 91-104, 2008.

Palmer, S. and Hall, W., Is Off-Campus Engineering Study Off the Agenda? Professional Accreditation and Distance Education, Eur. J. Open, Distance E-Learning, vol. 11, no. 2, pp. 1-9, 2008.

Palmer, S. and Holt, D., Students' Perceptions of the Value of the Elements of an Online Learning Environment: Looking Back in Moving Forward, Interact. Learning Environ., vol. 18, no. 2, pp. 135-151, 2010.

Palmer, S., Tolson, M., Young, K., and Campbell, M., The Relationship between Engineering Bachelor Qualifications and Occupational Status in Australia, Aust. J. Eng. Ed., vol. 20, no. 2, pp. 103-112, 2015.

Phillips, S.M. and Saraniti, M., A Fully Online Accredited Undergraduate Electrical Engineering Program, Proc. of the 2016 ASEE Annual Conf. and Exposition, New Orleans, LA, June 26-29, 2016.

Poudel, P.C., Statistical Analysis of Academic Results in an Engineering Physics Unit, MSc, Deakin University, Geelong, 2018.

Reiach, S., Cassidy, V., and Averbeck, C., The Evolution of Distance Education in Australia, Quart. Rev. Distance Ed., vol. 13, no. 4, pp. 247-252, 2012.

Scott, C.J., Petronella, A., Astatke, Y., and Ladeji-Osias, J.O., Useful Strategies for Implementing an Online Undergraduate Electrical Engineering Program, Proc. of the 2012 ASEE Annual Conf., San Antonio, TX, pp. 25.1413.1-13, June 10-13, 2012. 
Selvalingam, S., Billings, R., and Booth, D., Professional Standing of Partially or Wholly Licensed Engineering Programs in the Malaysian Context, Proc. of the 18th Conf. of the Australasian Association for Engineering Education, Melbourne, Australia, 2007.

Simonson, M., Smaldino, S., Albright, M., and Zvacek, S., Teaching and Learning at a Distance, 5th ed., Boston, MA: Allyn \& Bacon, 2012.

Singh, V. and Thurman, A., How Many Ways Can We Define Online Learning? A Systematic Literature Review of Definitions of Online Learning (1988-2018), Am. J. Distance Ed., vol. 33, no. 4, pp. 289-306, 2019.

Social Research Centre, QILT Surveys, accessed April 2, 2020, from https:// www.qilt.edu.au/qilt-surveys/, 2020.

Straumsheim, C., Online Ed Skepticism and Self-Sufficiency: Survey of Faculty Views on Technology, Inside Higher Ed, accessed from https://www.insidehighered.com/news/ survey/online-ed-skepticism-and-self-sufficiency-survey-faculty-views-technology, 2014.

Tang, W.K., Liu, P.L., Westgate, C.R., and Scalzo, K.A., Online-BSEE (Online Bachelor of Science in Electrical Engineering): A Multi-University Collaboration Project in Partnership with Open SUNY, Proc. of the 2015 ASEE Annual Conf. and Exposition, Seattle, WA, 2015.

TechSmith, Camtasia, accessed January 15, 2020, from https://www.techsmith.com/videoeditor.html, 2020.

Thirunavukarasu, G., Chandrasekaran, S, Betageri, V.S., and Long, J., Assessing Learners' Perceptions of Graduate Employability, Sustainability, vol. 12, no. 2, pp. 460.1 $-460.417,2020$.

Walkington, J., Pemberton, P., and Eastwell, J., Practical Work in Engineering: A Challenge for Distance Education, Distance Ed., vol. 15, no. 1, pp. 160-171, 1994.

Wells, J., Barry, R.M., and Spence, A., Using Video Tutorials as a Carrot and Stick Approach to Learning, IEEE Transact. Ed., vol. 55, no. 4, pp. 453-458, 2012.

Whiteman, W.E., A Survey of Distance Learning Programs that Offer a Master of Science in Mechanical Engineering Degree, Proc. of the 2012 ASEE Annual Conf., San Antonio, TX, June 10-13, 2012. 